\title{
CElTiC Military EQuiPMENT FROM THE TERRITORY OF UKRAINE: TOWARDS A NEW WARRIOR IDENTITY IN THE PRE-ROMAN EASTERN EUROPE ${ }^{1}$
}

\author{
GENNADIY KAZAKEVICH
}

\section{Introduction}

The lands of present day Ukraine are stretched across the distinct periphery of the 'Celtic world'. From the midfirst millennium BC the cultural background of this part of Eastern Europe was defined mainly by the Scythian culture of North Pontic steppes as well as by Hellenistic influences from the Greek colonies of the Black sea littoral zone and the kingdom of Bospor in the Crimea. However, starting from the early third century BC, the influence of the Central European La Tène culture extended to a much degree. This process was traditionally viewed as a result of either Celtic invasion (Machinskij 1974) or indirect trade contacts with the La Tène zone of Central Europe (Maksymov 1999).

Currently both 'migration-focused' and 'autochthon-based' approaches seem to be out of date. In recent studies, the Latènisation of Southern and Eastern Europe is interpreted as a culture-restructuring process affecting indigenous communities similar in many aspects to the Hellenisation of the Mediterranean region (see Džino 2007). The adaptation of La Tène cultural aesthetics and technical achievements, as well as Celtic linguistic elements caused the emergence of new ways of expressing identity. However, in some cases the traditional colonization paradigm still cannot be totally rejected. The aim of this paper is to show the finds of Celtic and related military equipment from the territory of

\footnotetext{
${ }^{1}$ The paper was read at the $14^{\text {th }}$ International Congress of Celtic Studies (Maynooth, August 1-5, 2011). I wish to thank the National University of Ireland, Maynooth, for the invitation to take part in the conference and their financial support. The research underlying this publication was funded by the American Council for Learned Societies. I would like to acknowledge the permission granted by Bilgorod-Dnistrovs 'kyj Regional Museum, Uzhgorod State Museum, National Museum of the History of Ukraine (Kyiv), Odesa Numismatics Museum to reproduce figures 2, 3, 6, 9, 12, 16.1, 16.3 as well as opportunity given by the Institute of Archaeology of National Academy of Sciences of Ukraine (Kyiv) to work on its unpublished materials and reproduce figures 1.3, 4, 5, 7. I express my gratitude to Prof. R. V. Terpylovs kyj (Kyiv), Dr. K. P. Bunatyan (Kyiv), J. Emilov (Sofia), Dr. M. Karwowski (Wien) for sharing their knowledge and valuable remarks on the topics discussed in the paper. I am also indebted to Dr. M. Fomin (Ulster) for the invitation to publish the paper in the present volume.
} 
Ukraine in the broad context of 'Latènisation' of Eastern Europe in the third - first centuries $\mathrm{BC}$ period.

\section{The weapons, horse and chariot gear from the Upper Tisza area}

The only region of present day Ukraine where La Tène sites are sufficiently widespread is the Upper Tisza basin (see Map 1).

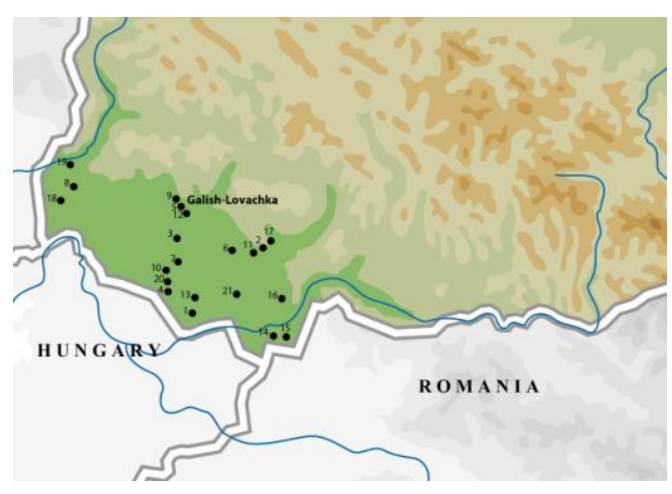

Map 1. The Upper Tisza basin

Between the seventh and the fourth centuries BC, the territory which lays south-westwards of the Carpathian mountains was occupied by the Kushtanovycya $^{2}$ culture primarily associated with the Northern Thracians. In the early third century $\mathrm{BC}$ the cultural situation in the region seemed to change radically. New technologies of the house

building, pottery making and metal-working were introduced in the Upper Tisza area and new centers of economical and political activity emerged. The most important one was the settlement on Galish and Lovachka hills near the modern town of Mukacheve (fig. A). The Galish-Lovachka site had been unsystematically excavated by a number of amateur archaeologists between 1844 and 1930. About a thousand items were found in the twenty four half-dugout dwellings and the occupation layer of the site (Bidzilya 1971: 30-8). Two inhumation graves with Celtic coins from Galish hill are the only known La Tène burials from this part of the Upper Tisza area. It is likely that the local La Tène group used a burial rite that left no archaeologically detectable traces (such situation was typical of many Eastern Celtic regions). Several cremation graves found in the region containing mixed Kushtanovycya and La Tène inventory seem to show not the indigenous influence on the local Celtic inhabitants

\footnotetext{
${ }^{2}$ Note that all modern place-names from the territory of Ukraine mentioned in both the paper and in the appendix are given according to the up-to-date Ukrainian spelling. The transliteration standard used is GOST 7.79 system B (the exception is Cyrillic letter " (" $и$ " in Ukrainian) which is transliterated as " $y$ " instead of " $y$ "). If necessary, the regional distribution of the sites, including their districts and regions is pointed out to simplify the verification of the data. It has to be taken into account that some Ukrainian towns and villages were renamed in the last two decades, and to avoid the confusion the older names are given in brackets.
} 
(Eremenko 1997: 36), but rather the adaptation of the La Tène fashion by either neighbouring or subdued Thracian population which at least partly preserved its cultural distinction.

The collection of Celtic military equipment from Galish-Lovachka consisted of a short sword with an X-shaped handle $(l=41 \mathrm{~cm})($ fig. 2$)$; two middle La Tène swords (72,5 and $75 \mathrm{~cm}), 12$ large curved knives, 27 spearheads, 2 javelin heads and 14 arrow heads (fig. 1.1), 9 iron chain belts for hanging a sword (fig. 1.2). The finds of horse gear and chariot fittings (Bidzilya 1971: 72-6, 80, fig. 17, 28-30) demonstrate that such an important element of the Celtic warfare as the use of cavalry and chariots was employed by the local population (fig. 1.4). In the early twentieth century, the cultural layer of the Galish-Lovachka site was mostly destroyed by the plantage ploughing. Additional research conducted in 1962 and 1964 was unsuccessful.

In 1988-1989, the archaeologists of Uzhgorod State University excavated several storage pits and a half-dugout dwelling $(4.1 \times 2.4 \mathrm{~m})$ on the Lovachka hill. The cultural layer contained the fragments of pottery (mostly wheel-made) and several metal goods, including the iron tip of the scabbard (Kotygoroshko 1988/150: 17-20, fig. 3; Balaguri, Kotygoroshko 1989/197, p. 19-21, fig. 21). V. Kotygoroshko who conducted the research states that during the excavations a dry stone wall was revealed along the crest of the Galish hill (2008: 126).

Apart from the Galish-Lovachka site, there are about two dozen La Tène sites in the Ukrainian part of the Upper Tisza basin. Most of them are the settlements that consisted of a few half-dugout dwellings of rectangular or improper form with the pillar structure of walls and storage pits. The fragments of pottery, both hand and wheel made, clay spindle whorls and rare metal goods are the typical items representing the material culture of those complexes. The military equipment is almost unknown and the fragment of an iron chain belt from Oleshnyk settlement (fig. 4) is the only exception (Penyak, Popovich, Potushnyak, 1977/18: 33-6, fig. 76). Only a few sites contained the remains of iron working which are known from the settlements of Bakta, Dyjda, Oleshnyk and Uzhgorod (see Appendix). The finds of glass slag from Dyjda prove the existence of at least one glass making workshop. Along with the small vici, there were highly specialised centers of metallurgy which consisted of working grounds where the remains of forges, slag and iron aggregations can be found (fig. 5). Nove Klynove, the largest of them, comprised about 200 forges (Bidzilya 1971: 21-30). 
Almost all La Tène sites in the area contained fragments of Kushtanovycya culture hand-made pottery. However, the settlement structures, the technologies of iron and glass working, wheel-made pottery making, the art style and other aspects of material culture of the La Tène sites of the region were unfamiliar to the local population before the early third century BC. The style of combat in which the long slashing swords, iron chain belts and chariots were used may also be considered as foreign to the indigenous population. Such rapid and radical changes cannot be explained in terms of cultural diffusion. It seems that the La Tène group of the Upper Tisza area demonstrates the classical pattern of migration and acculturation.

It is not clear when the La Tène sites of the Upper Tisza area were abandoned. Most scholars believe that the decline of the local Celtic settlements was caused by the military activity of the Dacians in the middle of the first centry BC, attested in the classical sources (Eremenko 1997: 35; Kotygoroshko 2008: 168). However, it should be emphasized that almost all La Tène objects with more or less precise dating may belong to LT C1-C2 period. In this regard, it is highly probable that the Celtic settlements of the Ukrainian part of the Upper Tisza area ceased to exist at least in the late second century BC. The La Tène artifacts dating to LT D period come exclusively from the Dacian sites of the region. Considering the fact that seven ritually bent late La Tène swords were excavated in the Dacian cemetery near the Mala Kopania hill-fort (Kotigorosko 2009: 36-7, fig. 29), it is possible to suggest that the Dacians adopted the elements of the Celtic weaponry.

\section{The La Tènised communities eastward of the Carpathians}

In contrast, the links between the Celtic mainland and the lands eastward of the Carpathian mountains which comprised the Scythia Magna for a long period of time were rather indirect. Some forms of La Tène jewellery were adopted by the North Pontic population as early as the fourth century BC. The early La Tène ribbed arm-rings are reported from various Getic, Scythian and Hellenistic sites within the territory of Ukraine, although most of them were produced locally (e.g., fig. 16.1, 3). The casting-form for the production of such arm-rings comes from the Greek colony Olbia in the Southern Bug firth (see Shchukin 1994: 96-101; Eremenko 1997: 202-9). There are about a dozen of the Duchcov fibulae (Ambroz 1966: 12) and a few La Tène neck-rings found in the lands of present day Ukraine (fig. 13-14). 


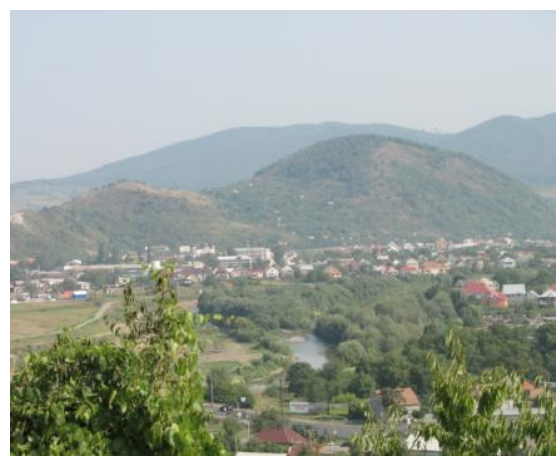

Fig. A. The modern town of Mukacheve

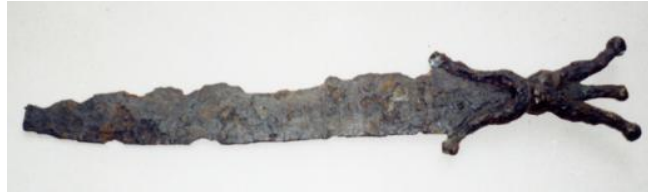

Fig. 2. Galish-Lovachka sword

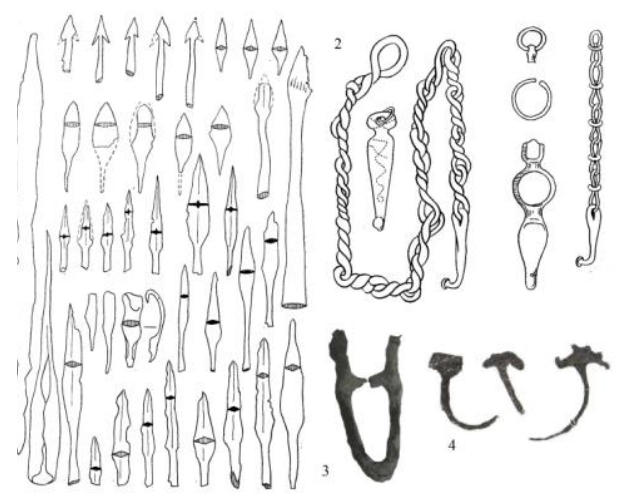

Figs. 1.1-1.4. Galish-Lovachka

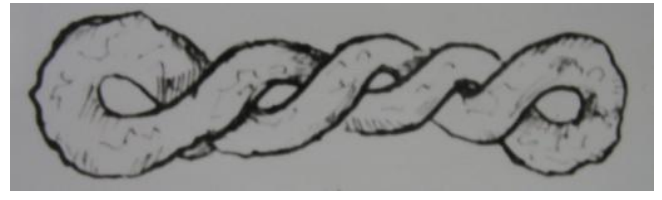

Fig. 4. Oleshnyk iron chain belt: fragment

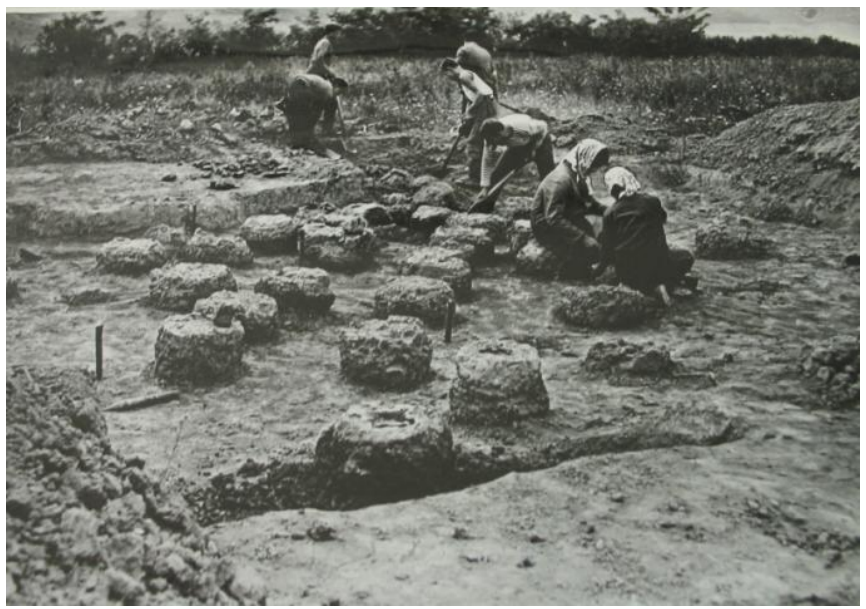

Fig. 5. Excavations at Nove Klynove in 1966 
However, most of them may be regarded as imports, perhaps with the exception of the Duchcov brooch from the cremation burial of Zalissya which also contained the clay La Tène-like urn (Belyashevskij 1904). The burial from Zalissya and the pottery-making workshop from Bovshiv in the Upper Dniester area (Krushelnitskaya 1965) are currently the only known 'pure' La Tène sites eastward of the Carpathians.

In the early second century $\mathrm{BC}$, the Poieneşti-Lukashevka and Zarubynci cultures emerged in the lands of Eastern Europe. The La Tène traditions of Temperate and South-Eastern Europe influenced both cultures to a great extent, but this was especially true in the case of the Zarubynci one. The bearers of the Poieneşti-Lukashevka and Zarubynci cultures adopted the wire middle La Tène brooches which are among the most widespread findings of the third-first centuries BC metalwork in the Eastern Europe. The Zarubynci culture bearers used to wear the middle La Tène fibulae with the triangular ending of stem (the so-called "fibula of the Zarubynci type"). Outside of the Zarybynci culture area such fibulae are known only in the lands of Scordisci in Middle Danube area. The La Tène influence is also evident in the funeral rite and pottery-making of the Zarubynci culture (see Pachkova 2006: 340-47). Hardly anything could be said about the military traditions of those cultures as the findings of weapons are scarce.

Some linguistic evidence reflecting the 'Celticisation' of the Eastern European cultural milieu is known as well. The Greek epigraphic decree in honour of Protogenes mentions the $\Gamma \alpha \lambda \alpha \tau \alpha$ threatening Olbia and the nearby Scythian tribes (Latyshev 1885: 37-40). The precise dating of the decree is unknown, although it may describe the events of either the late third century BC (Vinogradov 1989, p. 181-3) or the early second century BC (Andreeva 2004: 102). A. Falileyev notes an ethnic name 'O $\lambda \alpha \tau 1 \kappa o v$ from the Greek inscription found in the Bukovyna region which

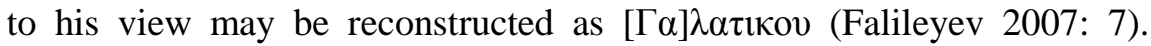
Some Celtic-like place and ethnic names were mentioned by Greek authors. Strabo (VI. 2. 3) and Plutarch (Mar. 11. 12) who used the records of Posidonius (late second century BC) noted a pseudo-ethnic entity

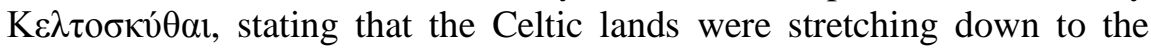
Moeotis littoral zone (the Azov sea). Claudius Ptolemy who used the sources dating to the turn of the eras mentions several place- and ethnic names on the lands of the Scythia Magna which currently are considered to be undoubtedly Celtic (Sims-Williams 2006: 218-19; Falileyev 2005; Falileyev 2007: 4-9). Among them are Kappóoovvov, Maıtóvıov and

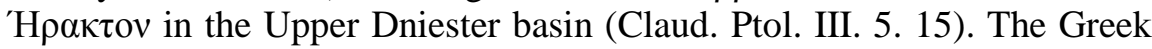

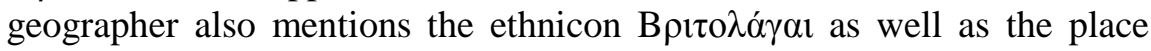




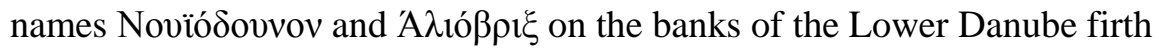
(ibid. III. 10. 7). In the year $63 \mathrm{BC}$ the Celtic mercenaries of Mithridates

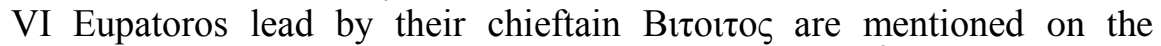
territory of the Bospor kingdom by Appian (Mithr. 111). ${ }^{3}$

\section{The La Tène swords from Scythia}

Probably, the most notable La Tène site in the North Pontic area is

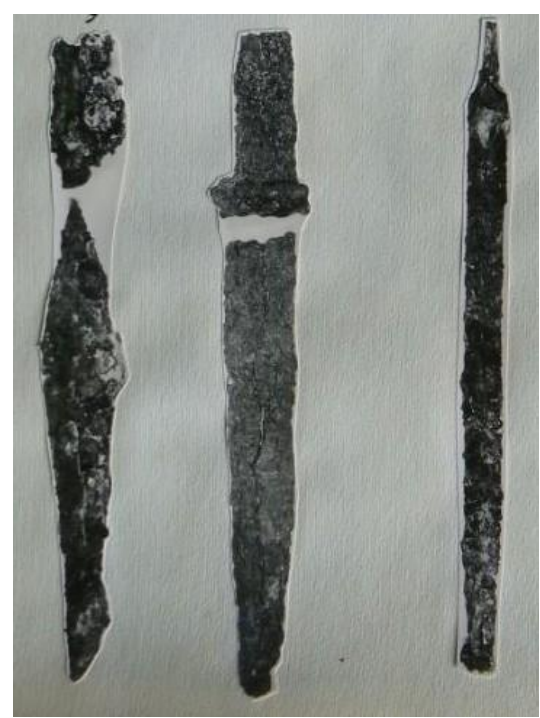

Fig. 7. The Vyshhetarasivka metal goods the inhumation burial from Vyshhetarasivka (also known as Verkhniaya Tarasovka) which contained a LT B2/C1-C2 sword $(l$ $=83 \mathrm{~cm})$, a head piece of a spear $(l$ $=40 \mathrm{~cm}$ ) and a fragmented brooch of an uncertain type. A. Bodiansky who excavated the grave in the late 1958 reported that its inventory contained also a Scythian "knife", 27 head pieces of arrows, a clay pot and a bead (Bodyanskij 1962). As a result, for a long time it was believed that Vyshhetarasivka grave reflected the contacts between Scythian and Celtic military elites. On the other hand, the arrow heads from the grave date back to the fifth century BC and, as K. Bunatyan informed me,

\footnotetext{
${ }^{3}$ Some Celtic-like toponyms are attested among the modern river-names of Ukraine in the area of the Zarubynci culture as well. For example, A. Falileyev supports the earlier O. Trubachov's view regarding the probable Celtic origin of the river-names Otavin (Отавин), Tynya (Тиня) and Tnya (Тня) in the Horyn' river basin. In his point of view, those river-names are comparable with the Celtic stem tauo < tauso- 'silencieux, tranquille' (Falileyev 2006: 72-73). Thus, A. Falileyev notes that no hydronym of Celtic provenance has been securely attested in the territories of the "eastern Celts", including the Balkans and North Western Dacia (ibid. 74). It is intriguing that not far from the Tnya river (in the distance of about $40 \mathrm{~km}$ ) there is a river Myka (Мика). While the Slavic etymology of this hydronym is problematic, it is comparable with Celtic moch 'boar, pig' (Old Irish mucc). It is known that until the mid-nineteenth century the alternative name for the Myka river was Svynoluzhka that may be roughly translated as 'a swine's rivulet' (currently the hydronym Svynoluzhka survived in the name of one of the Myka tributaries). However, one must note that the river-names mentioned above were documented as late as the twelfth century AD, so that their 'Celticity' shall always be doubtful.
} 
the iron "knife" is indeed the Scythian short sword which dates back to the sixth-fifth centuries BC. So, it is most likely that A. Bodyanskij, who was not a professional archaeologist, excavated two different graves. Unfortunately, all the findings from the Vyshhetarasivka site are now lost. If one were to judge by the only preserved photograph (fig. 7) the lower part of both the sword and scabbard was sufficiently damaged by corrosion which was the cause of A. Bodyanskij's misleading graphic reconstruction (see Shaposhnikova, Bodyanskij, Shchepinskij 1957/10b: 34-5; Bodyanskij 1962).

The items from Vyshhetarasivka are the only middle La Tène sword and scabbard found in the North Pontic region. However, some swords of this type also come from the North-Western littoral zone of the Black sea (Pavolche, Kalnovo, Kazanlak in Eastern Bulgaria). They were found in the warrior graves of a mixed La Tène, Thracian and Hellenistic inventory (Emilov 2007: 65-66; Emilov 2010: 76-77; Theodossiev 2005: 89-90).

It is also possible that the sword from Vyshhetarasivka belongs to either a gift or booty category. Furthermore, the burial could reflect the penetration of some Celticised warrior bands, possibly from Thrace. This suggestion may be proved by the findings of several double-spring $\mathrm{La}$ Tène brooches from the Panticapaeum and Lower Dnipro area (Shchukin 1994: 98-100, fig. 34.12, 15) which were widespread in Thrace in the third century BC. While the form of brooch was 'Celtic', some of the double-spring fibulae were produced in the Hellenistic settlements (Seuthopolis, Sboryanovo) (see Emilov 2010: 17-21; Lazarov 2010: 121, fig. 2.4). The findings of the double-spring fibulae are known from the Getic sites in Romania and Moldova. Some double-spring brooches along with middle La Tène wire fibulae with 8-like loops were found in the mound burials near Tiraspol in the Lower Dniester area (Pachkova 2006: 284, fig. 141.2). The cultural attribution of those mounds is unclear, however it is most probably that they were left by the ethnically heterogeneous population.

Two late La Tène swords come from the rich burials of the late Scythian kingdom in the Crimea. Both were found in the mausoleum in Neapolis which was used by the Scythian nobility from the late second century $\mathrm{BC}$ to the first century AD. It may be supposed that those artifacts attest the presence of some Celtic mercenaries in the Crimean Scythia during the Mithridatic wars. One of the swords was found in the burial of Skilurus (the king of Scythia Minor in the late second century BC) along with a large quantity of military equipment of Hellenistic and Scythian types (Zaycev 2003: 54-5, fig. 76). It is notable that the sword was 
previously broken - this may reflect a well-attested La Tène tradition to damage weapons before putting them into the grave. Another fine example of a long slashing sword from the mausoleum of Scythian Neapolis (fig. 8) was found in the grave of a Scythian warlord and his family members along with a late Etruscan bronze mirror (Treister 1993, fig. 4). The sword dates back to the La Tène $D_{1}$ period, having close parallels with the finds of Celtic weapons from Switzerland (Müller 2001: 529). It is important that some other graves of the Neapolis mausoleum contained the middle La Tène brooches of the so-called "Neapolis type".

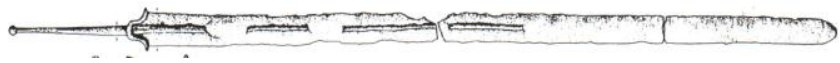

Fig. 8. The Scythian Neapolis La Tène D1 sword

Being widely distributed in both the Eastern Europe and Galatia in Asia Minor such brooches are almost unknown in the Celtic West.

\section{Bosporan oval shield depictions}

The North-Eastern part of the Black sea littoral zone contains further evidence of the Celtic warfare influence, most of which are various examples of the 'Celtic' oval shield from the Hellenistic Bospor kingdom (fig. 10). In the Hellenistic art, the oval shield (thureos) was the most
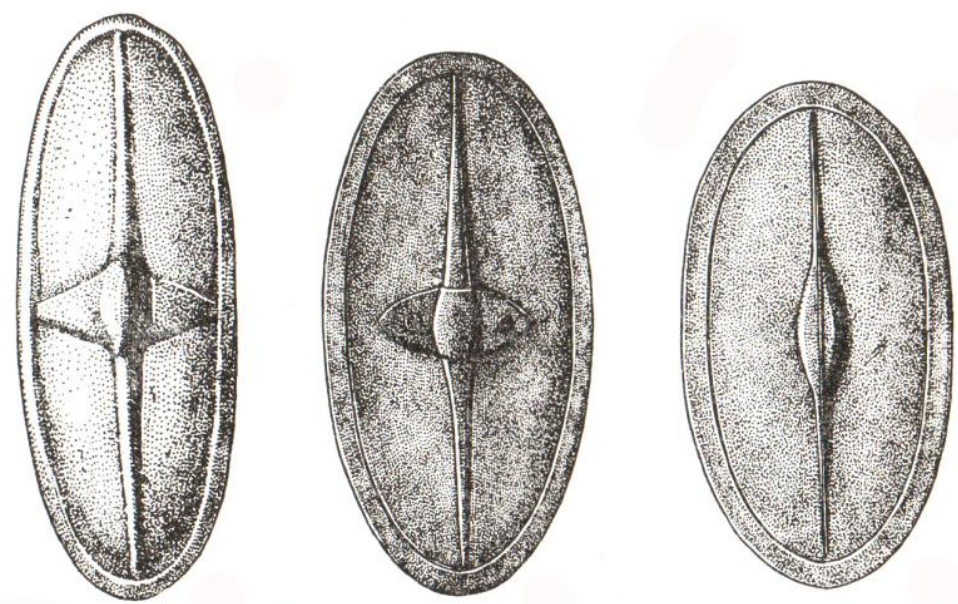

Fig. 10. The Bospor kingdom Hellenistic oval shield representations 
frequently used iconographic marker of a Celtic warrior (Bienkowski 1927). At least partly, this stereotype was based on Celtic beliefs. It is known that the Celts believed that the oval shield obtained some apotropaic potential (Polyaen. IV. 6. 17; Athenaeus, IV, 40.154 a-c). Taking such facts into consideration, some scholars concluded that the appearance of an oval shield on the Bosporan works of art reflects the presence of Celtic mercenaries in the Bospor kingdom (Pruglo 1966: 20513).

Recently it was proved that the oval shield and its various modifications were widely distributed among the non-Celtic peoples as well; in this regard, a direct association of the Bosporan artefacts with the Celts is questionable (Gunby 2002). Although the discussion concerning the Bosporan oval shields is far from being certain, it must be noted that their origin may have a different explanation in every individual case and the indirect Celtic influence is one of them.
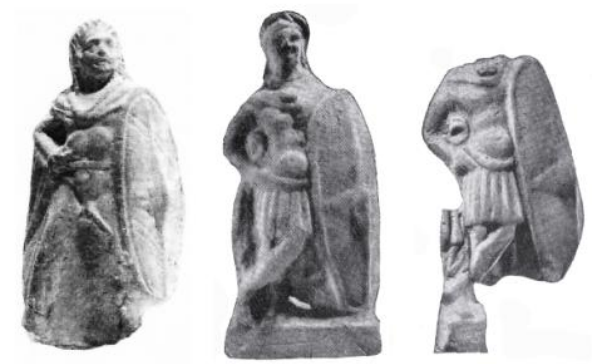

Fig. 11. Statuettes of Celtic mercenaries

The earliest Bosporan depiction of the oval shield comes from a fresco showing the Egyptian 'Isis' battleship (the mid-third century BC) in Nyphaeum. Four shields of almost rectangular form are depicted standing on board the ship (see Vinogradov 1999). It was suggested that those depictions may be interpreted as either a Ptolemaic dynastical emblem (Eichberg 1987: 193) or a typical element of the third century BC battleship equipment (Höckmann 1999: 318-19). Although it is still possible to suggest that the Ptolemaic diplomatic mission had been accompanied by some Celtic guardians who played an important role in Egyptian military forces. In the late third century BC, the bronze coins of Leucon II containing symbols of 'short sword/oval shield' were minted in Bospor kingdom. The historical context of their emergence is unclear, however in the late third century BC similar coins were minted in Thrace by Kavaros, the ruler of the Celtic kingdom Tylis and Hellenistic towns Apros and Mesambria (both likely to have been satellitic to the state of Kavaros at the time, Lazarov 2010: 113-121). Considering the Thracian origin of the Bospor ruling dynasty and close connections between the 
Bospor kingdom and the North-Western Pontic area it may be suggested that the oval shield representation was adopted by Leucon II as a symbol of political and military power in the region. The representations of the oval shield were frequently used in producing small terracotta statuettes of the 'warriors' (datable to the late third - first centuries BC; see fig. 11). Many of them have close parallels in Hellenistic art of the Mediterranean basin, e.g. the statuette of a Celtic mercenary commemorating the Egyptian victory in the Battle of Raphia c. 217 BC (Cunliffe 2000: 181). Let us bear in mind that diplomatic contacts between Egypt and the Bospor kingdom during the third century $\mathrm{BC}$ were particularly close and many Egyptian works of art arrived to the Bospor territory at that time (see Treister 1985). In this regard, it may be suggested that the majority of Bosporan oval shield depictions was influenced by the Ptolemaic art. Finally, it must be said that the oval shield (whether it was of Celtic origin or not) was adopted as a main defensive weapon of the Bosporan infantry in the last centuries BC.

\section{Montefortino type helmets from the North Pontic area}

Of other categories of military equipment once associated with the Celts

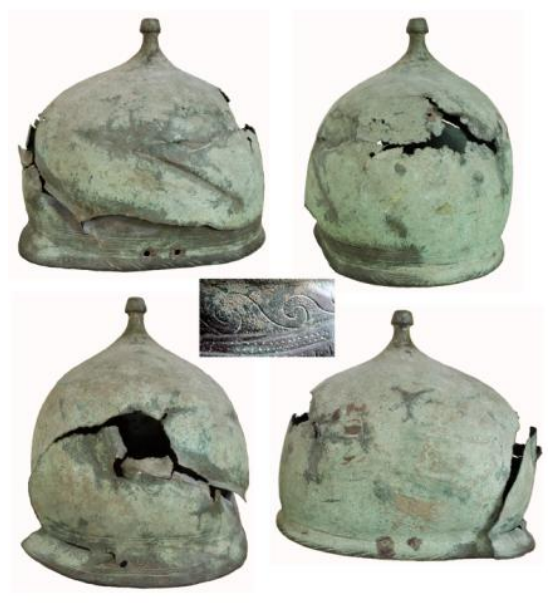

Fig. 9. The Bilen ke Montefortino type helmet, Bilgorod-Dnistrovs 'kyj

Regional Museum are the helmets of Montefortino type. There are about twenty of such bronze helmets found in the North Pontic and Azov area. Usually they were interpreted either as a trace of Celtic mercenary and military activity in the region or as the booty taken by Sarmatian warriors in Galatia during the Mithridatic wars (see Raev, Simonenko, Treister 1990; Treister 1993: 791-98). Currently, the Celtic attribution of the majority of the Montefortino type helmets seems doubtful. Although the introduction of Montefortino type helmets must be accredited to the 
Celts, only the items made of iron may be attributed to the production of Celtic armourers. Throughout Europe, the bronze Montefortino helmets were widespread mainly due to the Roman troops while among the Celts such helmets were only in limited use (Paddock 1993: 469-71).

Two of the Montefortino type helmets from Mar'yivka Domanivs'kyj district of Mykolayivska region and Vesela Dolyna Bilgorod-Dnistrovs 'kyj district of Odes 'ka region come from the votive hoards which contained also Scythian and Sarmatian jewellery and horse gear as well as Mediterranean bronze vessels. The votive hoards are attributed to the local nomadic population (either Scythian or Sarmatian). However, as Yu. Zaycev pointed out, the funeral rite exhibited in such complexes owes its origin to the Balkan and Danubian region (Zaycev 2007: 266). Other three helmets were found in Bilen'ke BilgorodDnistrovs 'kyj district of Odes 'ka region (fig. 9), Pryvillya Lysychans 'kyj district of Lugans'ka region and Tokmak-Mogyla mound near Novopoltavka Chernigivs'kyj district of Zaporiz'ka region. It is quite significant that the fragments of Montefortino helmet were found in the Tauri sanctuary Gurzufs 'ke Sidlo near Yalta in the Crimea along with a large number of items of Roman military equipment of the first century AD dating (Novichenkova 1998: 56). In this regard, it is most likely that the majority of Montefortino helmets penetrated into the Eastern Europe due to the Sarmatian contacts with Rome in the time of Mithridatic and Bosporan wars (first century BC - first century AD).

Some of them, however, (e.g. the helmet from Bilen'ke, datable to the late fourth - early third century BC) could reflect the Celtic military or mercenary activity in the North-Western Pontic area. In this connection, it is quite important that the Celtic context of the finds of the early Montefortino helmets from Athens and Thesprotia (Paddock 1993: 499, 501, fig. 133: 23, 146: 61) should also be invoked.

\section{The late La Tène weapons from the Gryniv and Mutyn sites}

The latest cultural impact from the La Tène zone reached the lands of Eastern Europe due to the Przeworsk culture widespread on the territory of present day Poland. According to the widely accepted point of view this culture emerged under the influence of the Northern European Jastorf culture and La Tène traditions of temperate Europe. Their funeral rite shows that at least the warrior elite of the Przeworsk culture bearers seems to have been 'Celticised'. The excavated warrior graves usually contain a full set of La Tène-like military equipment or even a double set of weapons. Most of the swords and spearheads had been bent or broken according to the already mentioned custom (see the end of section 2 
above), well-attested in the La Tène zone (see Czarnecka 1997; 2007). In last decades of the first century BC, the Przeworsk burials containing a large number of objects of La Tène military equipment emerged in the area of the Upper Dniester basin. Among the most notable finds are the five late La Tène swords from the burial ground Gryniv (Kozak 2008: 120, fig. 42.1-43.8). The grave no. 3 contained a unique scabbard with an open work decoration which in many ways is similar to the images of the Gundestrup cauldron. Its anthropomorphic and zoomorphic figures demonstrate a mixture of Celtic and Thracian art practices and religious beliefs (see Kazakevich 2010).

A late La Tène burial ground excavated at Mutyn gives another intriguing example of the penetration of a certain 'Celticised' war-band to the East. The Mutyn burial ground is located on the banks of the river Seim which is in the Middle Dnieper basin. To the present day, this is the furthest site to the East where the large quantities of the late La Tène military equipment had been revealed. The site was excavated in 20092010 and the outcome of the findings has not yet been published (see Terpilovskiy 2010). The cultural attribution of the Mutyn burial ground is not clear. R. V. Terpylovs 'kyj suggests that it may probably belong to the local cultural group of Har'yivka which presents a distinct combination of Zarubynci culture elements and late features of Jastorf and Przeworsk cultures.

R.V. Terpylovs'kyj who conducted the research of Mutyn site generously informed me of a dozen of exceptionally rich warrior graves excavated there. All the burials date back to the late first century BC. The graves contained 13 late La Tène swords, scabbards, spearheads, fragmented chain mails, round shield bosses etc. The most impressive are the finds of five late La Tène helmets. At least two of them belong to the Novo Mesto type similar to the helmets from Bela Cerkva and Stara Gradiška in Slavonia which were produced during the first century BC by the Celtic Taurisci (Božič 2001: 475, 477; Mikhaljević, Dizdar 2007: 125126). The finds of such helmets from outside the Middle Danube region are few, however one was found in the Przeworsk grave from Siemiechów (Poland) and the other two come from the Sarmatian burials from BoikoPonura and Yashkul (Russian Federation). 


\section{Conclusion}

The finds of the La Tène and related military equipment from the territory of Ukraine may be viewed from the perspective of a very complicated and disputable process of the 'Celticisation' of Eastern Europe.

From the early third century BC, the 'La Tène impact' transformed the cultural situation in the lands of present day Ukraine to a large degree. The subsequent changes led to the emergence of a new economical and social situation on the large territory from the Carpathian Mountains to the Middle Dnieper basin.

The archaeological situation in the Upper Tisza region demonstrates the colonisation carried out by the Celts from Central Europe in so far as their way of life differed from the indigenous population. They brought a new complex of weapons and introduced a previously unknown style of combat which included the use of war chariots, long slashing swords and chain belts.

The situation was completely different on the lands eastward of the Carpathians. Isolated 'Celtic' or 'Celticised' groups from temperate Europe penetrated into the region in the third-first centuries BC.

However, the indigenous warrior elite adopted the La Tène swords and helmets as symbolic objects reflecting a high social rank of their possessors. New ritual practices, styles of combat and loanwords (e.g. ethnic and place names containing Celtic elements) may have also been subsequently introduced in the region.

The emergence of the La Tène weaponry in the North Pontic steppes, Dniester and Dnieper basins therefore reflects a process of the new warrior identity formation in the local cultural milieu.

Taras Shevchenko National University of Ukraine, Kiev, Ukraine 


\section{Appendix}

\section{The Catalogue of the La Tène Sites, Imports and Stray Finds from the Territory of Ukraine}

\section{Preliminary remarks}

From the early twentieth century several attempts to complete an inventory of the La Tène findings from the territory of Ukraine were made. The majority of the finds from the Upper Tisza area (Zakarpats'ka obl.) was surveyed by V. Bidzilya (1971; supplemented by Bidzilya, Shchukin 1993). The results of the excavations carried out at the La Tène sites in the recent decades remained mostly unpublished (with some exception, e.g. Kotygoroshko 2008). The only available sources of more or less complete information on the La Tène sites of Upper Tisza area which were excavated since 1970 are the typewritten reports from the Archive of the Institute of Archaeology of the National Academy of Sciences of Ukraine.

The La Tène finds from the rest of the regions of present day Ukraine were overviewed in some papers devoted to the 'Celtic' artifacts from the Eastern Europe (e.g. Kuharenko 1959; Woźniak 1974; Shchukin 1994; Eremenko 1997). However, the methodology used in the publications mentioned above is questionable in many aspects. The main problem is the tendency to include the artifacts which are neither Celtic nor La Tène into the catalogues of the 'Celtic (La Tène) imports'. The indiscrete use of this information may to a large extent cause the overestimation of the total amount of the La Tène sites and finds from the territory of Ukraine. As an example of such approach one can allude to the paper by J. Clerc (2009) in which 556 objects from the territory of Ukraine are classified as 'Celtic'. In fact, the number of the Central European artifacts that can plausibly be classified as La Tène would seem to be at least ten times less. Let us mention in passing that the methodological approach which involves a direct association of 'La Tène' goods with the 'Celtic population' is simply out of date.

To avoid such misleading conclusions, some categories of finds which were previously considered to be 'La Tène' or 'Celtic' are omitted here. Among them are Italian bronze vessels and almost all of the Montefortino type bronze helmets, Hellenistic oval shield depictions, iron and golden boar figurines (as their attribution to the Scythian art seems doubtless), the indigenous replicas of the La Tène $\mathrm{B}$ ribbed arm-rings and most of the fibulae datable to the middle and late La Tène which were produced mostly by the local smiths (with the exception of several brooches of the 
rare types which may be considered as evident La Tène imports from the Temperate or Southern Europe).

\section{The La Tène sites of the Upper Tisza area (Zakarpats `ka region, Ukraine)}

Bakta (Beregivs 'kyj district): Three half-dugout dwellings $(4.4$ x $3.5 \mathrm{~m}$; $4.5 \times 3.3 \mathrm{~m} ; 4.7 \times 3.3 \mathrm{~m}$ ); hand-made and wheel-made pottery fragments; spindle whorls (4 in dwelling №1 and 3 in dwelling №2); fragment of a glass arm-ring (dwelling №1); a wire bronze fibula (fragment); an iron finger-ring; an iron buckle; an amber bead; some pieces of iron slag; large quantity of animal bones (small cattle, cows, wild boars) (Kotygoroshko 1982/109: 9; Balaguri 1986/57: 14-9, fig. 2.5-6, 2.8-10). Map 1.1.

Brid (Irshavs'kyj district): Working ground with slag and iron aggregations; cultural layer damaged; excavated in 1982 (Bidzilya 1982/157: 9). Map 1.2.

Dercen (Drisine) (Mukachivs 'kyj district; Mala Gora stove): A damaged half-dugout dwelling with scattered hand-made and wheel-made pottery fragments was found in 1973. Two years later another half-dugout dwelling with a storage pit of hand-made and wheel-made pottery was found (Penyak 1975/105: 2, 23-27, fig. 55, 56). In 1982, a damaged storage pit with hand-made and wheel-made pottery fragments was revealed. The cultural layer of the settlement was badly damaged by construction and agricultural works (Balaguri, Kotygoroshko 1983/152: 13, 21-22). Map 1.3.

Dyjda (Didove) (Beregivs'kyj district): Excavations of 1984 revealed a half-dugout dwelling and some pottery fragments, mostly wheel-made (Penyak, Popovich 1984/14: 27-30, fig. 41-42; Balaguri, Kotygoroshko 1984/59: 20). The excavations of 1985 revealed three half-dugout dwellings, hand-made and wheel-made pottery, two spindle whorls made of wheel-made pottery fragments, some iron goods of uncertain form, glass fragments, an iron and a glass slag (Kotygoroshko 1985/59, 11-6, fig. 2.1-4). Map 1.4.

Galish-Lovachka: Settlement on the Galish (204 m) and Lovachka (306 $\mathrm{m})$ hills near Mukacheve. The Celtic settlement ( $S=15$ ha) had been unsystematically excavated by amateur archaeologists between 1844 and 1930. Three inhumation burials were revealed. One of them was made in a pit rounded by stones with the inventory of more than 30 Celtic derivations of Philip II and Alexander the Great coins. In the early twentieth century, the occupation layer was mostly destroyed by the agricultural works. In 1988-89, a half-dugout dwelling (4.1 x $2.4 \mathrm{~m})$, several storage pits with small quantity of metal goods and lots of wheelmade and hand-made pottery fragments were excavated. The total amount 
of metal goods found in dwellings and occupation layer of the site reaches a thousand of items. Currently they are preserved in the State Museum of Uzhgorod. Among the goods are:

a) Iron tools: opener tips (32), reaping-hoops (22), scythes (18), anvils (7), sledge-hammers (2), hammers (6), pincers (1), rasp, drill tool, axes (55), chisels (30), gouges (13), adzes (10), hack-saw, knives (11), clippers (8) etc.;

b) Jewellery: 2 chain belts and lots of fragments, including five bronze and three iron arm-rings, bronze finger-rings, bronze leg-ring, one Duchcov fibula and 8 wire middle La Tène brooches;

c) Military equipment: short sword with $X$-shaped handle $(l=41 \mathrm{~cm})$; two middle La Tène swords (72,5 and $75 \mathrm{~cm}), 12$ large curved knives, 27 spearheads, 2 javelin heads, 14 arrow heads, iron tip of the scabbard;

d) Horse gear: bits (6), chariot fittings (3); e) Household goods: padlock, iron chain for hanging a cauldron; grain bruisers; hayforks etc.;

f) Pottery: 36 hand-made and wheel-made vessels, lots of fragments. The wheel-made ceramics amounts to appr. $30 \%$ of the pottery finds;

g) Smelting pots (2) and moulds (6) (Bidzilya 1971: 30-3; Kotygorohko 1988/150: 17-20, fig. 3; Balaguri, Kotygoroshko 1989/197, p. 19-21, fig. 21);

h) Coins: tetradrachmas (18), didrachm, drachmas (3) of nine types (Kopf ohne Kinn/Rad, W-Reiter, Vogel auf Zweig, Vogel auf Helm, Schnurrbart/Rosette, Audoleontyp, Audoleonmonogramm 1, Reiter mit kurzen Armen, Armloser Reiter, Schild + Kranz, Schild + Schwert) (Kolniková 2002). Map 1.5.

Gorbok (Irshavs'kyj district): Dwelling of uncertain construction; occupation layer with hand-made and wheel-made pottery fragments (Bidzilya 1971: 41). Map 1.6.

Gut (Garazdivka) (Beregivs'kyj district): Occupation layer with traces of dwellings and fireplaces, fragments of hand-made and wheel-made vessels. The most interesting find is a hoard of more than a hundred of silver derivations of Philipp II coins in the hand-made vessel (Bidzilya 1971: 47). According to E. Kolniková the coins are of Huşi-Vovrieşti and Südostdakien types (2002: 109). Map 1.7.

Holmok (Uzhgorods 'kyj district): A half-dugout dwelling (4.1 x $2.8 \mathrm{~m}$ ); hand-made and wheel-made pottery fragments (third-second centuries $\mathrm{BC}$ ); an iron chisel; a fragment of a grain bruiser (Balaguri, Kotigoroshko 1989/197; 6-8). Map 1.8.

Klyachanove (Mukachivs`kyj district): Occupation layer $(S=2 \mathrm{ha}$ ) with a large quantity of pottery fragments. Wheel-made La Tène ceramics make 
up about $30 \%$ of the total amount of the pottery finds. In 1954, the hoard of the La Tène iron tools (four axes, opener tip, chisel and cylindrical hand-punch) had been found on the Obuch ridge near Klyachanove village by the farmers. All the items are currently on display at the State Museum of Uzhgorod (Bidzilya 1971: 46). Map 1.9.

Mala Bigan ' (Beregivs 'kyj district): The pottery vessel of uncertain form containing small figurines of a boar and a human, a fragmented glass armring (LT C1), a fragment of a bronze leg-ring found by farmers in 1952. The figurines and the glass arm-ring are now in possession of the State Museum of Uzhgorod (Bidzilya 1971: 46). Map 1.10 (fig. 3).

Midyanytsya (Irshavs kyj district): Two working grounds with slag and iron aggregations. Excavated in 1983 and 1987 (Penyak, Popovich, Potushniak 1983/5: 2; Kotigoroshko 1987/143: 8-9). Map 1.11.

Mukacheve: Occupation level with a large quantity of wheel-made pottery revealed during the water pipe construction on the Zamkova street (Bidzilya 1971: 41-42; Kotygoroshko 2008: 126). Map 1.12.

Muzhyeve (Beregivs'kyj district): Two half-dugout dwellings; fragments of 25 wheel-made and 35 to 40 hand-made pottery vessels. Excavated in 1982 (Balaguri, Kotigoroshko 1983/152: 20-21). Map 1.13.

Nevetlenfolu (Dyakove) (Vynogradivs kyj district): A damaged pit and cultural layer with hand-made and wheel-made pottery which was revealed in 1970 in the Nad Eger stove (Balaguri 1970/50: 2-3). In 1972, at the Tekerev stove the working ground with 97 forges, 10 fireplaces, 4 storage pits had been excavated (Balaguri, Potushnyak, Penyak 1972/97: 87-88). Map 1.14.

Nove Klynove (Vynogradivs 'kyj district): 15 working grounds with slag agglomerations and more than 130 forges occupying a territory of approximately 50 ha on the left bank of the Botar river. Few fragments of hand-made and wheel-made pottery. The remains of forges and iron slag are known from nearby villages Yulivci, Volchans'ke and Chepe (Bidzilya, Shhukin 1993: 70-71). Map 1.15.

Oleshnyk (Vynogradivs 'kyj district): Two half-dugout dwellings (4.8x5.7 $\mathrm{m}$; $4.8 \times 3.6 \mathrm{~m}$ ); wheel-made (22\%) and hand-made (78\%) pottery; a small curved knife $(l=11 \mathrm{~cm})$; fragment of a chain belt (fig. 4); a chisel; two iron goods of uncertain form and iron slag in dwelling no. 24; fragment of a wire fibula (?); three spindle whorls. Excavated in 1977 (Penjak, Popovich, Potushnyak, 1977/18: 33-6, fig. 76). A. Ostroverhov with reference to $\mathrm{V}$. Kotygoroshko mentions the find of a glass arm-ring fragment (2007: 142-143). Map 1.16. 
Osiy (Irshavs 'kyj district): Several dwellings; occupation layer with handmade and wheel-made pottery fragments; three spearheads (Bidzilya 1971: 41).Map 1.17.

Rativci (Uzhgorods 'kyj district): Five dwellings; storage pits. Ceramic findings are represented mostly by fragments of hand-made vessels and to a lesser degree by wheel-made pottery fragments (Bidzilya 1971: 39). Map 1.18.

Uzhgorod: Three to five settlements in different districts of the city; stray finds: a) On the territory of the modern brickyard two dug-out dwellings with wheel-made pottery fragments were excavated. Several bronze finger-rings and arm-ring with knobs were found also.

b) The second settlement represented by the occupation layer with handmade and wheel-made pottery fragments on the Uzhgorod's castle hill.

c) The third settlement revealed during the excavations of the Slavic site Radvanka (eastern suburb of Uzhgorod). Occupation layer is represented by hand-made and wheel-made pottery fragments (Bidzilya 1971: 40-41). In 1976 iron slag pieces and some wheel-made pottery fragments were revealed.

d) Lysa Gora stove (northern suburb of Uzhgorod). Cultural layer with small pottery fragments (mostly hand-made). One fragment contained traces of iron slag. Excavated in 1976.

e) Mlaki stove (northern suburb of Uzhgorod). Damaged cultural layer with wheel-made La Tène pottery fragments and iron slag. Excavated in 1976 (Medvedev 1976/115: 2-10). Map 1.19.

Velyka Bigan' (Beregivs`kyj district): 1986 excavations revealed three dwellings; hand-made and wheel-made pottery fragments (Balaguri 1986/57: 7-8). 1987 excavations: two half-dugout dwellings ( $S=11.7$ and $15.6 \mathrm{~m}$ ); hand-made and wheel-made pottery fragments (Kotigoroshko 1987/143: 10-11). A. Ostroverhov citing V. Kotygoroshko mentions the fragment of a glass arm-ring found in dwelling 1 of the settlement (2007: 142-143). Map 1.20.

Verhni Remety (Irshavs'kyj district): Dwelling with hand-made and wheel-made pottery fragments; fragment of a spindle whorl (Bidzilya 1971: 41). Map 1.21.

\section{The La Tène goods from the Kushtanovycya and Dacian burials of the Upper Tisza area (Zakarpats 'ka region, Ukraine)}

Bobove (Vynogradivs'kyj district): Cremation burial under the mound. The grave contained 16 black glass beads, fragment of a wire fibula, some fragments of a chain belt, three hand-made vessels of the Kushtanovycya 
type, two wheel-made La Tène vessels. The late La Tène painted vase is of particular interest (Bidzilya 1971: 44).

Kushtanovycya (Mukachivski district): The burial ground of the Kushtanovycya culture. The cremation grave in the burial mound no. 11 contained an inventory of items (wheel-made urn, three bronze fibulae, fragments of a bronze chain belt), all exclusively La Tène. Excavated in 1931 (Bidzilya 1971: 44).

Kolodne (Irshavs 'kyj district): The burial ground of the Kushtanovycya culture. Among the grave goods of the Kushtanovycya types, a wheelmade La Tène vessel (mound no. XV) and some fragments (mounds nos. IX, XI) were excavated by G.I. Smirnova in 1958 (Bidzilya 1971: 45).

Machola (Beregivs'kyj district): The burial ground with badly damaged cremation graves unsystematically excavated in 1932. Most of the grave goods are now lost. The glass arm-ring and the wheel-made La Tène urn are currently kept in the State Museum of Uzhgorod (Bidzilya 1971: 45).

Onokivci (Uzhgorods'kyj district): A wheel-made La Tène urn from the burial ground of the Kushtanovycya culture (Bidzilya 1971: 45-46).

Mala Kopanya (Vynogradivs'kyj district): Seven ritually bent late La Tène swords from Dacian burial ground near the Mala Kopanya hill-fort; fragmented glass arm-rings (Kotigorosko 2009: 36-7: fig. 29).

\section{The La Tène sites and stray finds from the lands eastward of the Carpathians}

Berezhanka (Chemerovec 'kyj district, Hmelnyc'ka region): Fragments of golden torques of possible La Tène origin in the hoard of uncertain cultural attribution (Vynokur 1969; Shhukin 1994: 99). In spite of the finds' similarity to the goods made by the Celtic craftsmen, it must be said that one of the fragments is close to the Havor type of torques which are known from the Baltic (Havor in Jutland, isle of Gotland, Trollhättan in Sweden) and the North Pontic (Olbia and Zalevki in Ukraine) regions. It is likely that the fragmented torque from the Dacian cemetery in Mala Kopanya belongs to the same type (Kotigoroshko 2009: fig. 40). Although the style of the torques had been inspired by the Celtic art; it is most likely that all of them were produced in the first-second century AD (Shchukin 2005: 73-81). The fact that the fragments of a hand-made pottery vessel found along with the golden torques from Berezhanka dates back possibly to the Roman period makes the Celtic attribution of the hoard even more problematic. Currently, the goods from the Berezhanka hoard are kept in the Kam'yanec'-Podil's kyj Museum. Map 2.1.

Bilen 'ke (Bilgorod-Dnistrovs'kyj district, Odes`ka region): An early Montefortino type bronze helmet. Stray find (Brujako, Rossokhatskiy 1993). The early date of the helmet (the late fourth - early third century 
BC) as well as other La Tène finds from the nearby area of Tyras make an attribution of the helmet to a Celtic mercenary possible. Currently, the helmet is kept in the Bilgorod-Dnistrovs 'kyj Regional Museum. Map 2.2 (fig. 9).

Biyivci (Boguslavs 'kyj district, Kyivs`ka region): A double-spring fibula (La Tène B2/C1). A stray find (Bidzilya, Shhukin 1993: 74, 82, tab. XVIII.6). Map 2.3 (fig. 14.6).

Borodyanka (Kyivs'ka region): A La Tène C fibula. A stray find (Pachkova 2006: 223, fig. 26). Map 2.4 (fig. 15.3).

Bovshiv (Galyc'kyj district, Ivano-Frankivs`ka region): A half-dugout dwelling $(2.4 \times 2.4 \mathrm{~m})$; a pit with a pottery stove; fragmented La Tène pottery of the second-first centuries BC; fragmented hand-made pottery of the Pomorsk or Poieneşti-Lukashevka culture (Krushelnitskaya 1965; Maksimov 1999: 146). Map 2.5 (fig. 17).

Chersk (Manevyc'kyj district, Volyns 'ka region): An iron Duchcov fibula (La Tène B - C1) (Kukharenko 1961: 68, tab. 9.2). Map 2.6.

Dniester estuary: Seven derivations of the Hellenistic coins found in different locations. Among them are: a golden 1/8 stater with Heracles head on obverse and a horse head on reverse; a silver didrachm; a silver drachma; four lead drachmas. Silver and lead coins are supposed to be derivations of the Philip II minting (Alekseev, Loboda 2004: 91-94). The coins are currently in the possession of the Odesa Numismatics Museum. Map 2.7 (fig. 12).

Dublyany (Lvivs'kyj district, Lvivs'ka region): An iron Duchcov fibula (La Tène B - C1) in the Pomorsk culture burial (Ambroz 1966: 12, tab. 2.1). Map 2.8 (fig. 14.2).

Galych (Ivano-Frankivska region): A La Tène C fibula (fragment). A stray find (Ambroz 1966: 19). Map 2.9 (fig. 15.5).

Golovne (Lubomls'kyj district, Volyns`ka region): A bronze Duchcov fibula (La Tène B - C1) in the Pomorsk culture burial (Kukharenko 1961: 62, 64, tab. 5.13). Map 2.10 (fig. 14.3).

Gorodnycya (Gorodenkivs`kyj district, Ivano-Frankivs`ka region): A La Tène $\mathrm{C}$ fibula of a rare type; stray find. The Celtic attribution of the fibula is questionable. M. Babeş supposes the Baltic origin of the brooch (2005: 122-125, fig. 1, 2). Map 2.11 (fig. 15.1).

Grygorivka (Mohyliv-Podils'kyj district, Vynnyts 'ka region): A bronze La Tène C fibula; stray find (Artamonov 1955: ris. 41.2.3). Map 2.12 (fig. 14.2).

Gryniv (Pustomytivs 'kyj district, Lvivs'ka region): Four late La Tène swords (some of them seem to be of local production), all ritually bent; scabbard with cut-out anthropomorphic and zoomorphic figures (Kazakevich 2010). Map 2.13. 


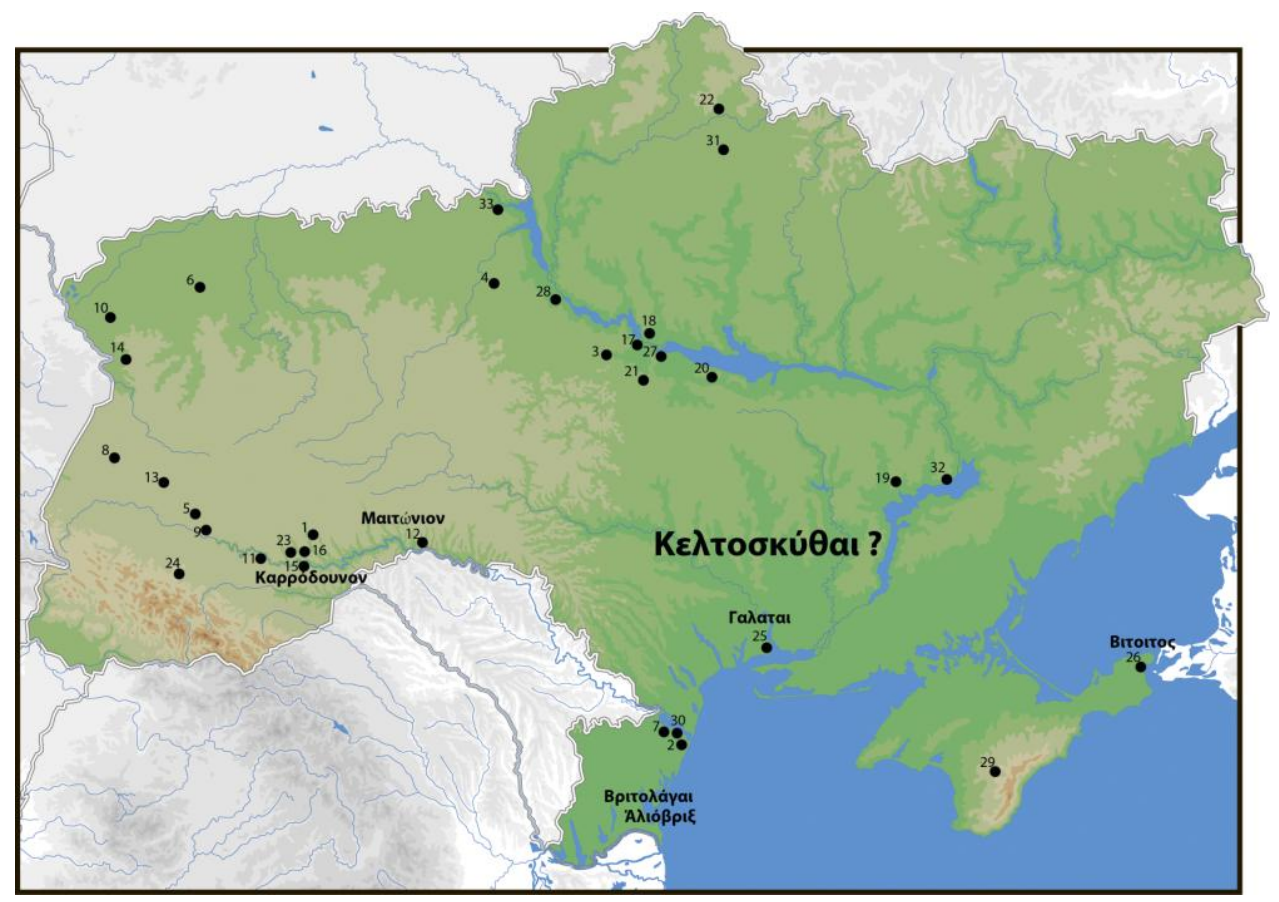

Map 2. The La Tène sites, imports and stray finds eastward of the Carpathians

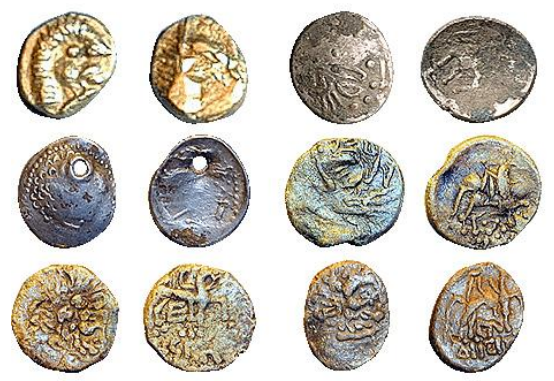

Fig. 12. The Dniester estuary coins, Odesa Numismatics Museum
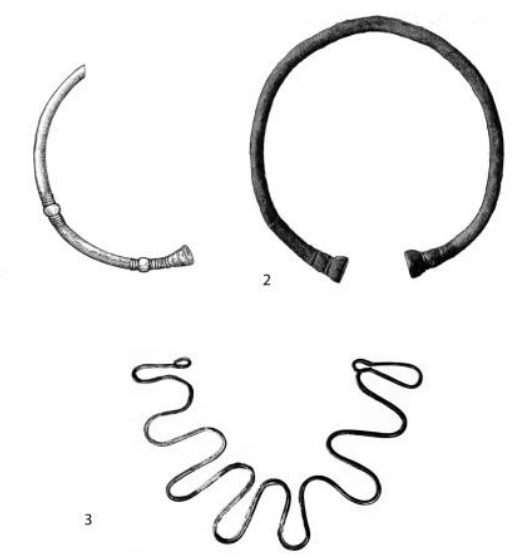

Fig. 13. Bronze La Tène neck-rings 
Holodne (Volodymyr-Volyns'kyj district, Volyns'ka region): An iron early La Tène fibula of the unknown type; stray find (Kukharenko 1959: 45). Map 2.14.

Horoshove (Zalishchyc kyj district, Ternopils'ka region): Fragments of the second-first century BC La Tène pottery along with the fragments of sapropelite arm-rings in two dwellings of the Poieneşti-Lukashevka culture settlement (Pachkova 1983: 45, fig. 10.6). Map 2.15.

Ivane Puste (Borshivs'kyj district, Ternopils'ka region): An early La Tène arm-ring from the Getic settlement (Ganina 1965, fig. 2.4). Map 2.16 (fig. 16.3).

Kaniv (Cherkas'ka region): An early La Tène arm-ring from the Scythian settlement (Khanenko, Khanenko 1899: tab. XI. 62, 67). Map 2.17 (fig. 16.4).

Liplyave (Kanivs 'kyj district, Cherkas 'ka region): Two bronze Duchcov fibulae (La Tène B - C1) on the territory of a Scythian hill-fort (Ambroz 1966: 12; Petrov 1961: tab. III.8). Map 2.18 (fig. 14.4-5).

Lower Dnipro area: Two double-spring fibulae (La Tène B2/C1). Stray finds made by A. Bodiansky; cultural context is unknown (Bidzilya, Shchukin 1993: 74, tab. XXVII.10, 11; Shchukin 1994: 99). Map 2.19 (fig. 14.7).

Makariv ostriv (the stove (?) near Cherneche Chygyryns'kyj district, Cherkas 'ka region): A bronze La Tène (?) neck-ring (fragment); stray find from the excavation of the early medieval Slavic settlement (Prykhodniuk 1980: fig. 45.2; Shchukin 1994: 99). Map 2.20 (fig. 13.1).

Mel nykivka (Smilyans'kyj district, Cherkas'ka region): A bronze La Tène (?) neck-ring; stray find (Bobrinsky 1910: fig. 38; Shchukin 1994: 99). Map 2.21 (fig. 13.2).

Dublyany (Lvivs kyj district, Lvivs'ka region): An iron Duchcov fibula (La Tène B - C1) in the Pomorsk culture burial (Ambroz 1966: 12, tab. 2.1). Map 2.8 (fig. 14.2).

Galych (Ivano-Frankivska region): A La Tène C fibula (fragment). A stray find (Ambroz 1966: 19). Map 2.9 (fig. 15.5).

Golovne (Lubomls'kyj district, Volyns'ka region): A bronze Duchcov fibula (La Tène B - C1) in the Pomorsk culture burial (Kukharenko 1961: 62, 64, tab. 5.13). Map 2.10 (fig. 14.3).

Gorodnycya (Gorodenkivs 'kyj district, Ivano-Frankivs'ka region): A La Tène $\mathrm{C}$ fibula of a rare type; stray find. The Celtic attribution of the fibula is questionable. M. Babeş supposes the Baltic origin of the brooch (2005: 122-125, fig. 1, 2). Map 2.11 (fig. 15.1). 

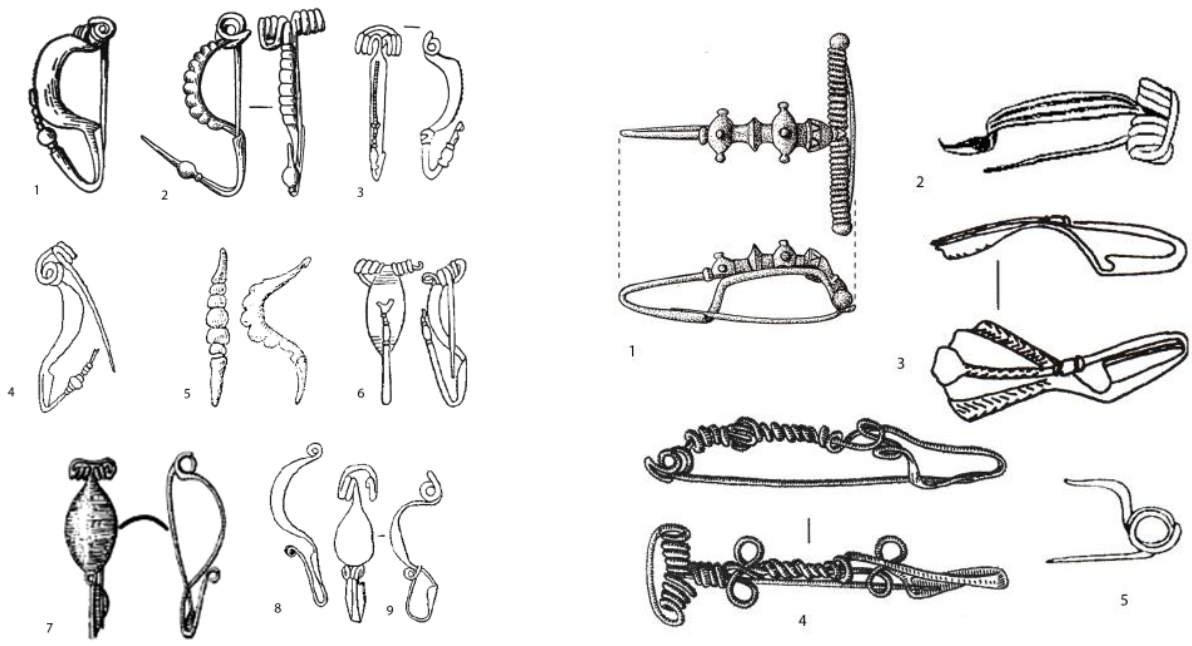

Fig. 14. Early La Tène fibulae

Fig. 15. Middle La Tène fibulae
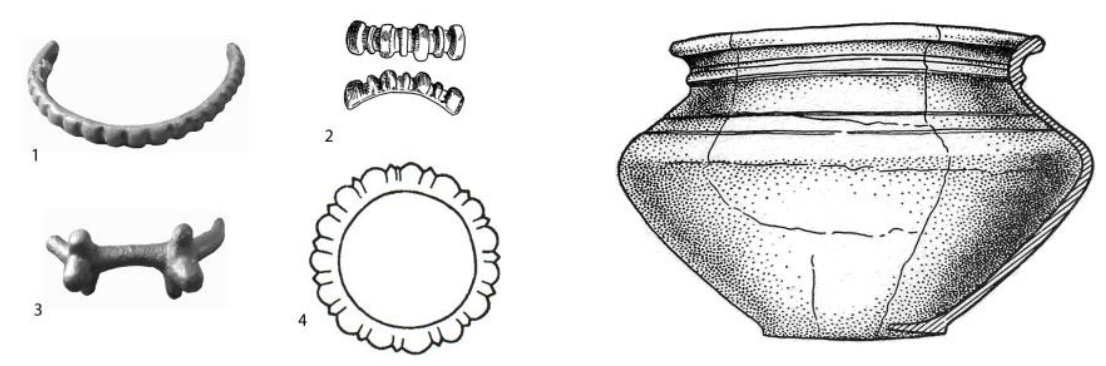

Fig. 16. Early La Tène arm-rings

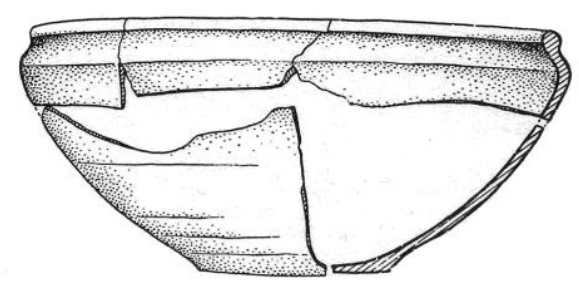

Fig. 17. Bovshiv La Tène wheel-made pottery 
Grygorivka (Mohyliv-Podils 'kyj district, Vynnyts'ka region): A bronze La Tène C fibula; stray find (Artamonov 1955: ris. 41.2.3). Map 2.12 (fig. 14.2).

Mutyn (Krolevetsky district, Sumska region): About a dozen of late La Tène swords, 5 Novo Mesto type helmets and other military equipment from the La Tènized Khar'yevka type graves (see Terpilovsky 2010). Excavations carried out between 2009-2010; most of the outcomes are not yet published. Map 2.22.

Novosilka (Zalishchyc'kyj district, Ternopils'ka region): Fragments of painted late La Tène pottery on the Lypytsya culture settlement (Kukharenko 1959: 45; Bandrivskiy, Josypyshyn 1997: 10). Map 2.23.

Nyzhnya Stynava (Stryjs'kyj district, Lvivs'ka region): Late La Tène sword, fragment of another sword along with horse gear and pottery in the burial of uncertain cultural attribution (Bandrivsky, Yosepyshyn 1997: 910). Map 2.24.

Olbia (Greek colony near the village of Parutyne Ochakivs 'kyj district, Mykolayivs 'ka region): There are no objects found in Olbia which may be evidently considered as imports from the Celtic lands. However, the Greek colony played a role of a production centre for the local La Tènelike goods. The casting-form for the La Tène B-C bronze arm-rings production came from Olbia as well as a comparably large quantity of the middle La Tène wire brooches, including the fibulae of the so-called 'Olbian type' (see Vinogradov 1989: 182). Map 2.25.

Panticapaeum (today's Kerch in the Crimea): Two double-spring fibulae (La Tène B2/C1); stray finds (Ambroz 1966: 12, 14, tab. 1.8, 9). Map 2.26 (fig. 14.8-9).

Pekari (Kanivs'kyj district, Cherkas'ka region): A wire neck-ring (fig. 13.3), a bronze "mask" ( $\mathrm{h}=3 \mathrm{~cm}$; fig. 6), early La Tène arm-rings (fig. 16.1, 16.2); stray finds (Kukharenko 1959: 49). All the items (with exception of a neck-ring) are currently in possession of the National Museum of the History of Ukraine in Kyiv. Map 2.27.

Pyrogiv (currently a southern suburb of Kyiv): La Tène C fibula in the Zarubynci culture burial (Pachkova 2006: fig. 25.1). Map 2.28 (fig. 15.4).

Scythian Neapolis (present day Simferopol in the Crimea): Two late La Tène swords along with several La Tène $\mathrm{C}$ fibulae of the Neapolis type. Found in the mausoleum of Skilurus, the king of little Scythia (late second century BC). One of the swords $(l=102 \mathrm{~cm}$, fig. 8) comes from a rich grave of a Scythian warlord (box 2). Another burial in the grave contained a late Etruscan mirror. The sword is currently kept in the Pushkin Museum of Fine Arts, Moscow (Treister 1993: 792-793, fig. 4). The 
second sword comes from the tomb of Skilurus that contained a large quantity of military equipment. The sword had previously been broken before it was deposited into the grave (Zaycev 2003: 55, fig. 79.1). Map 2.29 .

Tyras (Greek colony on the territory of today's Bilgorod-Dniestrovs 'kyj town): M. Karwowski called my attention to the find of Eastern Celtic glass arm-ring from Tyras which belongs to group 15 according to the Haevernick's classification (Ostroverhov 2007: fig. 3). Currently, the armring is preserved in the Bilgorod-Dnistrovs kyj Regional Museum. Another glass bracelet possibly belongs to the group 6b; however, the quality of its drawing (ibid., fig. 1.5) does not permit making any plausible conclusions. According to A. Ostroverhov, the arm-rings are dated to the La Tène C1b-C2 period (ibid., 143). Map 2.30.

Vovkivci (Romens 'kyj district, Sums'ka region): Two La Tène C fibulae in the burial of uncertain cultural attribution. Found along with glass beads, a golden finger-ring, a bronze mirror and various items of pottery (Khanenko, Khanenko 1900: 8-9, tab. XLIV.355-356, 462). Map 2.31.

Vyshhetarasivka (Tomakivs'kyj district, Dnipropetrovs 'ka region; other names of the site, e.g. Verkhniaja Tarasovka and Skel'ki, are incorrect): An inhumation burial which contained the La Tène B2/C1-C2 sword $(l=$ $83 \mathrm{~cm})$, a head piece of the spear $(l=40 \mathrm{~cm})$ and a fragmented brooch of the uncertain type. The drawing of the sword from the A. Bodyanskyj's paper (1962) is approximate (see Shaposhnikova, Bodyanskij, Shchepinskij 1958; Bodyanskij 1962). Map 2.32 (fig. 7).

Zalissya (Chernobyl's 'kyj district, Kyivs'ka region): A cremation burial unsystematically excavated in 1900. A hand-made clay urn of the form similar to La Tène wheel-made pottery containing a bronze Duchcov fibula. On the same site the fragments of the early La Tène arm-rings were found. All the items are currently lost (see Belyashevskiy 1904). Map 2.33 (fig. 14.1).

\section{Bibliography}

Alekseev, V., Loboda, P., 2004, Antichnye i srednevekovye monety Severnogo Prichernomor'ya [Ancient and medieval coins of the North Pontic area ], vol. 3, Odessa: Polis.

Ambroz, A., 1966, Fibuly juga Evropejskoj chasti SSSR [Fibulae from the South of the European part of the USSR], Svod arheologicheskih istochnikov [= Corpus of archaeological sources], nos. D1-30, Moskva: Nauka. 
Andreeva, S., 2004, 'Eshhe raz k voprosu o datirovke dekreta v chest' Protogena' [Once more regarding the date of the Protogenes decree], Bosporskiy fenomen [= The Bosphor phenomenon] 5, 95-103.

Artamonov, M., 1955, 'Arheologicheskie issledovanija v Juzhnoj Podolii v 1952-1953 gg.' [Archaeological research in Southern Podolia in 19521953], Kratkie soobschenija Instituta Arheologii [= Brief Proceedings of the Institute of Archaeology] 59, 100-117.

Babeș, M., 2005, 'The Brooch from Horodnica: Dacian, Celtic or Germanic?', in: Dobrzańska, H., Megaw, V. \& P. Poleska, eds., Celts on the Margin, Krakow: Institute of Archaeology and Ethnology of the Polish Academy of Sciences, 121-129.

Bandrivskiy, J., \& J. Josypyshyn, 1997, 'Kelty na zahodi Ukrainy' ['The Celts in the West of Ukraine'], Ukraina v mynulomu [= Ukraine in the Past 9, 8-16.

Belyashevskij, N., 1904, 'Pole pogrebalnyh urn epohi La Tène v Radomyslskom uezde Kievskoj gubernii' [Urn-field of the La Tène Age in the Radomysl district of the Kiev region], Arheologicheskaja letopis' Juzhnoj Rossii [= Archaeological Chronicle of Southern Russia], 1-2, 1318.

Bidzilya, V., 1971, Istoriya kultury Zakarpattia na rubezhi nashoyi ery [The History of Culture of Transcarpathian Area at the Turn of the Era], Kyiv: Naukova dumka.

Bidzilya, V., \& M. Shhukin, 1993, 'Pamyatniki latenskoj kultury na territorii Zakarpat'ya i k vostoku ot Karpat' [The Sites of the La Tène Culture on the Territory of the Transcarpathian area and Eastwards of the Carpathians], in: Rybakov, B., ed., Slavyane $i$ ih sosedi $v$ konce I tysiachiletiya do n.e. - pervoj polovine I tysiachiletija n. e. [The Slavs and Their Neighbours in the Late First Millennium BC - the First Half of the First Millennium AD], Moskva: Nauka, 67-84.

Bienkowski, P., 1927, Les Celtes dans les arts mineurs Greco-Romaine, Cracovie: Imprimerie de l'Université des Jagiellons.

Bobrinskij, A., 1910, 'Otchet o raskopkah v Chigirinskom uezde Kievskoj gub. v 1907-1908 gg.' [Report on the Excavations in the Chigirin district of the Kiev region in 1907-1908], Izvestiya Arheologicheskoj komissii $[=$ Proceedings of the Archaeological Commission] 35, 48-85.

Bodyanskij, A., 1962, 'Skifskoe pogrebenie s latenskim mechom v Srednem Podneprov'e' [Scythian Burial with a La Tène Sword in the Middle Dnieper Area], Sovetskaya arkheologiya [= Soviet Archaeology] 1, 272-276. 
Božič, D., 2001, 'Les Taurisques', in: Moscati, S., ed., Les Celtes, Paris: EDDL, 471-477.

Brujako, I., Rossohatskiy, A., 1993, 'Kel'to-italijskij shlem iz kollekcii Belgorod-Dnestrovskogo muzeya' ['A Celtic-Italian Helmet from the Collection of the Belgorod-Dniestrovsky Museum'], Peterburgskij arheologicheskij vestnik [Petersburg Archaeological Bulletin] 7, 78-80.

Clerc J., 2009, 'Chronology and Characterization of Celtic Finds in Ukraine', in: Karwowski, M., Droberjar, E., eds., Archaeologia Barbarzyńców 2008: powiazania i kontakty w świecie barbarzyńskim, Rzeszow: Mitel, 71-76.

Cunliffe, B., 2000, The Ancient Celts, Harmondsworth: Penguin Books. Czarnecka, K., 1997, 'Germanic Weaponry and its Celtic Background', Journal of Roman Military Equipment Studies 8, 291-297.

Czarnecka, K., 2007, 'Brothers-in-Arms? Graves from the Pre-Roman Period Furnished with Double Set of Weaponry', Archaeologia Baltica 8, 47-56

Džino, D., 2007, 'The Celts in Illyricum - Whoever They May Be: the Hybridization and Construction of Identities in South-Eastern Europe in the Fourth and Third Centuries BC', Opuscula archaeologica, 31, 49-68.

Eichberg, M., 1987, Scutum. Die Entwicklung einer italisch-etruskischen Schieldform von den Anfängen bis zur Zeit Caesars, Frankfurt a. M.: Peter Lang.

Emilov, J., 2007, 'The La Tène Finds and Indigenous Communities in Thrace. Interrelations during the Hellenistic period', Studia Hercinia 11, 57-75.

Emilov, J., 2010, 'Ancient Texts on Galatian Royal Residence of Tylis and the Context of La Tene Finds in Southern Thrace' in: Vagalinski, L. F., ed., In Search of Celtic Tylis in Thrace (III c. BC), Aberystwyth, Sofia, 67-87.

Eremenko, V. E., 1997 "Kel tskaya vual" i zarubineckaya kul tura [The "Celtic Fringe" and Zarubyntsi Culture], St. Petersburg: Izdatel'stvo Sankt-Peteburgskogo Universiteta.

Falileyev, A., 2005, 'Celtic Presence in Dobrudja: Onomastic Evidence', in: Cojocaru, V., ed., Ethnic Contacts and Cultural Exchanges North and West of the Black Sea from Greek Colonization to the Ottoman Conquest, Iaşi, 291-303.

Falileyev, A., 2006, 'Altkeltischer Sprachschatz: Ukrainian Contribution', in: Mac Mathúna, S. \& M. Fomin, eds., Parallels between Celtic and Slavic: Proceedings of the First International Colloquium of Societas Celto-Slavica, Studia Celto-Slavica 1, Coleraine: TSO Publishers, 71-74. 
Falileyev, A., 2007, Celtic Dacia. Personal Names, Place-names and Ethnic Names of Celtic Origin in Dacia and Scythia Minor, Aberystwyth: CMCS.

Ganina, O., 1965, 'Poselennya skifs 'kogo chasu v s. Ivane Puste' ['Settlement of the Scythian period in Ivane Puste'], in: Arheologia [= Archaeology] 19, 106-117.

Gunby, J., 2002, 'Oval Shield Representations on the Black Sea Littoral', in: Oxford Journal of Archaeology 19.4, 359-65.

Höckmann, O., 1999, 'Naval and Other Graffity from Nymphaion', Ancient Civilizations from Scythia to Syberia 5.4, 302-56.

Kazakevich, G., 2010, 'The Late La Tène Decorated Scabbard from the Upper Dniester Area: a Far Relative of the Gundestrup Cauldron?', in: Fomin, M., Jarniewicz, J., Stalmaszczyk, P., eds., Dimensions and Categories of Celticity: Studies in Literature and Culture. Part 2. Studia Celto-Slavica 5, Łódź: Łódź University Press, 171-9.

Kozak, D. N., 2008, Venedy [The Venedians], Kyiv: Instytut Arheologii.

Khanenko B., Khanenko V., 1899-1900, Drevnosti Podneprovja [Antiquities of the Dnieper area], Vols. 1-2, Kiev.

Kolniková, E., 2002, 'Latenezeitlicher burgwall Gališ-Lovačka (Mukačevo) im lichte der münzfunde', Karpaty $v$ davnynu [= The Carpathians in the Ancient Times] 15, 99-115.

Kotigorosko, V., 2009, Mala Kopanya, Satu-Mare: Editura Muzeului Sătmărean.

Kotygoroshko, V., 2008, Verhne Potyssia v davnynu [The Upper Tisza Area in Ancient Times], Uzhgorod: Karpaty.

Kuharenko, Yu., 1959, 'Rasprostranenie latenskih veshhej na territorii Vostochnoj Evropy' ['Distribution of the La Tène Goods on the Territory of Eastern Europe'], Sovetskaya arheologiya [= Soviet archaeology] 1, 31-51.

Kuharenko, Yu., 1961, 'Pamyatniki zheleznogo veka na territorii Polesya' ['The Iron Age Sites on the Territory of Polesye'], Svod arheologicheskih istochnikov [= Corpus of Archaeological Sources], nos. D1-29, Moskva: Nauka.

Krushelnickaya, L., 1965, 'Keltskij pamjatnik v Verhnem Podnestrov'e' ['The Celtic Site on the Upper Dniester'], Kratkie soobshchenija Instituta Arheologii [Brief Proceedings of the Institute of Archaelogy] 105, 119122.

Latyshev, B., 1885, Inscriptiones orae Septentrionalis Ponti Euxini Graecae et Latinae, Vol. 1, Petropoli. 
Lazarov, L., 2010, 'The Celtic Kingdom with its Capital Tylis in the Time of Kauaros', in: Vagalinski, L. F., ed., In Search of Celtic Tylis in Thrace (III c. BC), Aberystwyth, Sofia, 113-30.

Machinskiy, D., 1974, 'Kelty na zemliah k vostoku ot Karpat' ['Celts at the Lands to the East of the Carpathians], in: Yartseva, V. N., ed, Kelty $i$ keltskie jazyki [Celts and the Celtic Languages], Moscow: Nauka, 31-41.

Maksymov, E., 1999, 'Pro perebuvannia keltiv v Ukraini' ['About the Celtic Presence in Ukraine'], in: Terpylovs'kyj R., ed., Etnokulturni procesy v Pivdenno-Skhidniy Evropi v I tysiacholitti do n. e. [Ethnic and cultural processes in South-Eastern Europe in 1 millenium BC], Kyiv, Lviv: RAS, 143-50.

Mihaljević, M., Dizdar, M., 2007, 'Late La Téne Bronze Helmet from the River Sava near Stara Gradiška', Vjesnik Arheološkog muzeja u Zagrebu, 3.s.XL, 117-46.

Müller, F., 2001, 'Les armes celtique de la Zihl prés de Port', in: Moscati, S., ed., Les Celtes, Paris: EDDL, 528-9.

Novichenkova, N., 1998, 'Rimskoe voennoe snariazhenie iz sviatilishcha u perevala Gurzufskoe Sedlo' ['Roman Military Equipment from the Sanctuary near Gurzufskoye Sedlo Passage'], Vestnik drevnej istorii [= Ancient History Bulletin] 2, 51-67.

Ostroverhov, A., 2007, "Braslety "kelts'kogo" typu iz pam'yatok Ukrainy III-I st. do n. e. y deyaki pytannya istorii sklarstva antychnogo chasu' ['The Bracelets of the 'Celtic' Type from the Third-First Centuries BC Ukraine Sites and Some Questions of the Glass-making History in Ancient Times], Starozhytnosti stepovogo Prychornomor'ya i Krymu [= The Antiquities of North Pontic Steppes and Crimea] 14, 139-193.

Pachkova, S., 1983, 'Arheologicheskie issledovaniya mnogosloynogo poseleniya u s. Gorosheva Ternopolskoj obl.' ['Archaeological Research of the Multi-layered Settlement near Gorosheva Ternopol Region'], in: Arheologicheskie pamyatniki Srednego Podnestrov'ya [= Archaeological sites of Middle Dniester area], Kiev: Naukova dumka, 4-54.

Pachkova, S. P., 2006, Zarubineckaya kul'tura i latenizirovannye kul'tury Evropy [The Zarubyntsi Culture and La Tènised Cultures of the Europe], Kyiv: Instytut Arheologii.

Paddock, J., 1993, The Bronze Italian Helmet: the Development of the Cassis from the Last Quarter of the Sixth Century BC to the Third Quarter of the First Century AD, London, Vol. 2.

Petrov, V., 1961, 'Zarubynetsko-korchevatska kultura Serednioho Podniprovja' ['The Zarubinecko-Korchevatskaya Culture of the Middle Dnipro Area'], Arheologia [= Archaeology] 12, 53-75. 
Pruglo, V., 1966, 'Pozdneellinisticheskiye bosporskiye terracoty, izobrazhajushchiye voinov' ['Late Hellenistic Terracotas Depicting Warriors], in: A. Boltunova, ed., Kul'tura antichnogo mira [= The Culture of Classical World], Moscow: Nauka, 205-13.

Pryhodniuk, O., 1980, Arheologichni pamyatky Seredniogo Podniprovya VI - IX st. n. e. [The Archaeological Sites of the Middle Dnieper Area of the Sixth-Ninth centuries AD], Kyiv: Naukova dumka.

Raev, B., Simonenko, A., Trejster, M., 1990, 'Etrussko-italijskie i keltskie shlemy v Vostochnoj Evrope' ['Etruscan-Italic and Celtic Helmets in Eastern Europe], in: Drevnie pamjatniki Kubani [= Kuban Antiquities], Krasnodar, 117-35.

Redina, E., Simonenko, A., 2002, 'Klad konca II - I v. do n. e. iz Veseloj Doliny v krugu analogichnyh drevnostej Vostochnoj Evropy' ['The Late Second-First Century BC Hoard from Veselaya Dolina in the Context of Eastern European Archaeological Antiquities'], in: Materialy $i$ issledovaniya po arkheologii Kubani [= Materials and Research regarding the Archaeology of Kuban] 2, 78-96.

Shhukin, M. B. 1994, Na rubezhe er. Opyt istoriko-arheologicheskoy rekonstrukcii politicheskih sobytiy III v. do n.e. $-I$ v. n.e. $v$ Vostochnoy $i$ Centralnoy Evrope [On the Turn of the Era. An Attempt to Reconstruct a Model of Political Events in Eastern and Central Europe during the Third Century BC - First Century AD], St. Petersburg: Farn Ltd.

Shhukin, M. B., 2005, Gotskiy put' (goty, Rim i chernyakhovskaya kul'tura) [The Gothic Way (Goths, Rome and the Culture of the Chernyakhov)], St. Petersburg: Filologicheskiy Fakul tet SanktPeterburgskogo Gosudarstvennogo Universiteta.

Sims-Williams, P., 2006, Ancient Celtic Place-Names in Europe and Asia Minor, Oxford \& Boston: Blackwell Publishing.

Terpilovskiy, R., 2010, 'A Cremation from the Turn of the Era and the Sites of Khar'yevka Type in the Middle Seym Area', in: Inter ambo maria. Contacts between Scandinavia and the Crimea in the Roman period, October, 21-25, 2010. International conference: Abstracts, Simferopol, 142-6.

Theodossiev, N., 2005, 'Celtic Settlement in North-western Thrace during the Late Fourth and Third Centuries BC: Some Historical and Archaeological Notes', in: Dobrzańska, H., Megaw, V. \& P. Poleska, eds., Celts on the Margin, Krakow: Institute of Archaeology and Ethnology of the Polish Academy of Sciences, 85-92. 
Treister, M., 1985, 'Bospor i Egipet v III v. do n. e.' ['Bospor and Egypt in the 3rd Century BC'], Vestnik drevnej istorii [= Bulletin of the Ancient History] 1, 126-139.

Treister, M., 1993, 'The Celts in the North Pontic Area: a Reassessment', Antiquity, 67, 257, 789-804.

Vinogradov, Ju., 1989, Politicheskaya istoriya Olviyskogo polisa. VII - I vv. do n. e. Istoriko-epigraficheskoe issledovanie [Political History of Olbian Polis of the Seventh-First Centuries BC. Historical-epigraphic Research], Moscow: Nauka.

Vinogradov, Ju., 1999, 'Der staatbesuch der "Isis" im Bosporos', in: Ancient civilizations from Scythia to Siberia 5.4, 271-302.

Vynokur, I., 1969, 'Berezhans 'kyj skarb' ['The Berezhanka Hoard'], in: Bidzilya V., ed., Slovjano-ruski starozhytnosti [Slavonic-Russian Antiquities], Kiev: Naukova dumka, 14-21.

Woźniak, Z., 1974, Wschodnie pogranicze kultury lateńskiej, Wrocław: Ossolineum.

Zaycev, Yu., 2003, Neapol' Skifskiy (III v. do n. e. - III v. n. e.) [The Scythian Neapolis (Third century BC - Third century AD)], Simpheropol: Universum.

Zaycev, Yu., 2007, 'Kompleks iz Gevani (k probleme hronologii III v. do n. e.)' [Complex from Gevan' (to the Problem of the Third Century BC Chronology], Bosporskiy fenomen [= Bosporan phenomenon] 8.1, 258268.

\section{Unpublished reports from the Archive of the Institute of Archaeology of the National Academy of Sciences of Ukraine}

Balaguri, E., 1970/50, Zvit pro rozkopky ta rozvidky v Uzhgorods 'komu, Muachivs 'komu, Beregivs komu ta Vynogradivs 'komu r-nah [The report on the excavations and surveys in the Uzhgorods 'kyj, Beregovs 'kyj and Vynogradivs 'kyj districts].

Balaguri, E., 1986/57, Arheologicheskie issledovaniya $v$ zonah stroitel stva meliorativnyh sistem $v$ bassejne Verhnego Potis `a [Archaeological research in the areas of the ameliorative system construction in the Upper Tisza basin].

Balaguri, E., Kotigoroshko, V., 1984/59, Arheologicheskie issledovanija $v$ zonah stroitelstva meliorativnyh sistem na territorii Zakarpatskoj obl. USSR $v 1984 \mathrm{~g}$. [Archaeological research in the area of ameliorative system construction on the territory of the Zakarpatskaya region of the Ukrainian SSR in 1984]. 
Balaguri, E., Kotigoroshko, V., 1983/152, Arheologicheskie issledovanija $v$ zonah stroitelstva $\mathrm{m} / \mathrm{s}$ na territ. Zakarpatskoj obl. $v 1983$ g. [Archaeological research in the area of ameliorative system construction on the territory of the Zakarpatskaya region in 1983].

Balaguri, E., Kotigoroshko, V., 1989/197, Arheologicheskie issledovaniya $v$ zonah st-va meliorativnyh sistem i spasatel no-ohrannye raskopki oppiduma Gallish-Lovachka, gorodishha Malaya Kopanya [Archaeological research in the area of ameliorative system construction and protective conservation excavations of the Galish-Lovachka oppidum and the Malaya Kopanya hill-fort].

Balaguri, E., Penyak, S., Potushniak, M., 1972/97, Arheologichni doslidzhennia $v$ zonah melioratyvnyh robit $u$ Vynogradivskomu $i$ Beregivskomu raionah Zakarpatskoi oblasti URSR $1972 r$. [Archaeological research in the area of ameliorative works on the territory of the Vynogradivs 'kyj and Beregivs 'kyj districts of the Zakarpatskaya region of the Ukrainian SSR].

Bidzilya, V., 1966-1967/26, Otchet o rabote Zakarpatskogo otryada Ranneslavyanskoj ekspedicii za 1966-1967 gg. [Report on the works of the Transcarpathian detachment of the Early Slavic expedition in 1966-1967]. Bidzilya, V., 1982/157, Otchet istoriko-tehnicheskoj ekspedicii [Report of the historical-technical expedition].

Kotigoroshko, V., 1987/143, Otchet ob isledovanijah v zonah st-va meliorativnih sistem $v$ bassejne Verhnego Potisja [Report on the research works in the area of ameliorative system construction in the Upper Tisza basin].

Kotigoroshko, V., 1982/109, Otchet ob arheologicheskih issledovanijah v zone stroitel'stva meliorativnyh sistem na territorii Zakarpatskoj oblasti USSR $v 1982 \mathrm{~g}$. [Report on the archaeological research in the area of ameliorative system construction on the territory of the Zakarpatskaya region of the Ukrainian SSR].

Kotigoroshko, V., 1985/59, Arheologicheskie issledovanija $v$ zonah stroitelstva meliorativnyh system [Archaeological research in the area of ameliorative system construction].

Kotigoroshko, V., 1988/150, Arheologicheskie issledovanija $v$ zonah stroitelstva meliorativnyh sistem $v$ bassejne verhnego Potis'ja $i$ spasatel'no-ohrannye raskopki oppiduma Gallish-Lovachka i gorodishcha Malaja Kopanja [Archaeological research in the area of ameliorative system construction in the Upper Tisza basin and protective conservation excavations of the Galish-Lovachka oppidum and Malaya Kopanya hillfort $]$. 
Medvedev, A., 1976/115, Otchet o razvedovatel nyh rabotah v 1976 g. Arheologicheskoj sekcii Zakarpatskoy oblorganizacii Obshhestva ohrany pamyatnikov istorii $i$ kultury [The report on the archaeological surveys in 1976 of the Archaeological section of the Trans-Carpathian regional branch of the Society for protection of monuments of history and culture]. Penyak, S., 1975/105, Zvit Zakarpats koyi novobudivnoi arheologichnoi ekspedycii pro poliovi doslidzhennia [The report of the Trans-Carpathian new construction expedition on the field works].

Penyak, S., Popovich, I., 1984/14, Otchet Zakarpatskoj novostroechnnoj ekspedicii o razvedkah i raskopkah $1984 \mathrm{~g}$. [The report of the TransCarpathian new construction expedition on the surveys and excavations].

Penyak, S., Popovich, I., Potushniak, M., 1977/18, Otchet ob ohrannyh raskopkah $v$ zonah novostroek $v$ Zakarpatskoj oblasti USSR $v 1977$ godu [The report on the protective excavations in the areas of new construction in the Zakarpatskaya region of the Ukrainian SSR in 1977].

Penyak, S., Popovich I., Potushniak, M., 1983/5, Otchet Zakarpatskoj novostroechnoj ekspedicii o razvedkah i raskopkah $1983 \mathrm{~g}$. [The report of the Trans-Carpathian new construction expedition on the surveys and excavations in 1983].

Shaposhnikova, O., Bodyanskij, O., Shchepinskij, A. 1957/10b, Zvit pro robotu Dniprovs 'kogo zagonu Dniprovs koyi ekspedyciyi [The report on the works of the Dnieper detachment of the Dnieper expedition].

\section{List of maps}

Map 1. The La Tène sites of the Upper Tisza area (the Zakarpats'ka region, Ukraine).

Map 2. The La Tène sites, imports and stray finds from the lands eastward of the Carpathians.

\section{List of figures}

Fig. A. The Galish and Lovachka hills. View from Mukacheve castle.

Fig. 1.1-1.4. The La Tène military equipment and chariot fittings from Galish-Lovachka (after Bidzilya 1971; Kotygoroshko 1988/150).

Fig. 2. The short sword with X-shaped handle from Galish-Lovachka (Uzhgorod State Museum). 
Fig. 3.1-3.3. The bronze figurines of a human (3a) and a boar (3b) (photos by I. Baran), glass La Tène $\mathrm{C} 1$ arm-ring (3c) from the Mala Bigan' hoard (Uzhgorod State Museum).

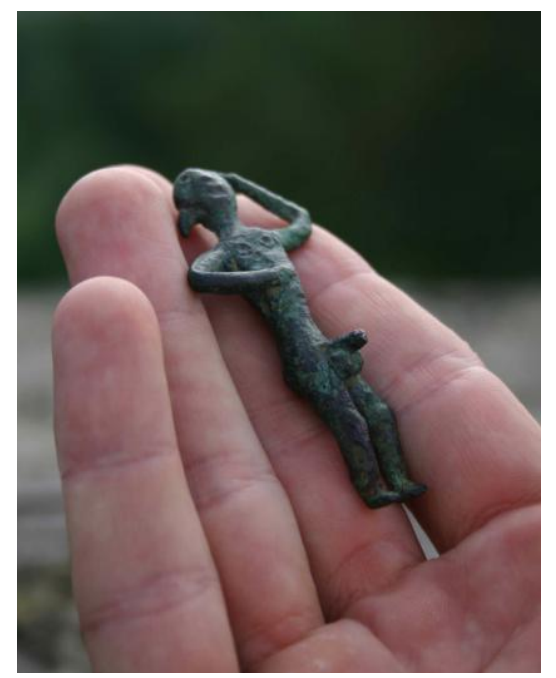

Fig. 3a. Human bronze figurine

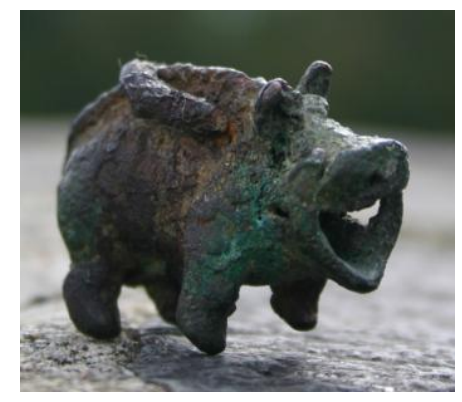

Fig. 3b. A boar bronze figurine

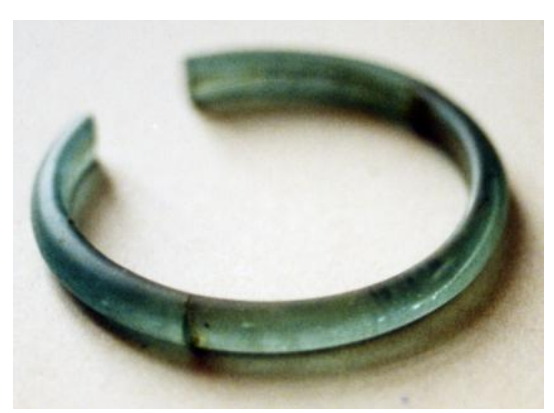

Fig. 3c. Glass La Tène C1 arm-ring

Fig. 4. The fragment of the iron chain belt from Oleshnyk (Penyak, Popovich, Potushniak 1977/18).

Fig. 5. The excavations of the Iron Age metallurgy working ground at Nove Klynove in 1966. The remains of forges and slag aggregations are clearly visible (after Bidzilya 1966-1967/26). 


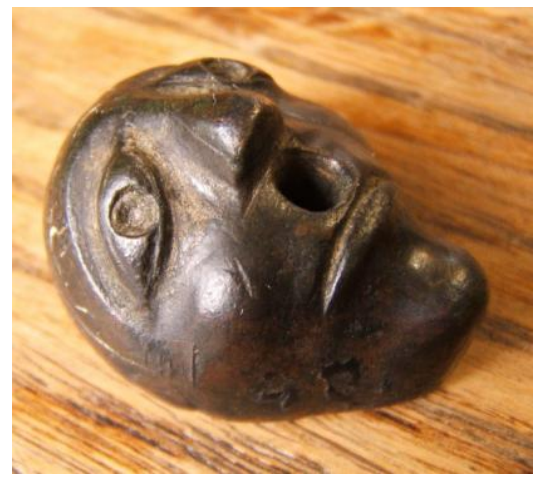

Fig. 6. The Pekari bronze mask
Fig. 6. The bronze mask from Pekari (National Museum of History of Ukraine, Kyiv).

Fig. 7. The metal goods from Vyshhetarasivka burial: a fragmented spearhead $(1=40 \mathrm{~cm})$, a Scythian short sword (6-5 c. BC), a La Tène B2-C sword (after Shaposhnikova, Bodyanskij, Shchepinskij 1957/10b.).

Fig. 8. The La Tène D1 sword from the Scythian Neapolis (after Treister 1993).

Fig. 9. The Montefortino type helmet from Bilen'ke (BilgorodDnistrovs'kyj Regional Museum).

Fig. 10. The Hellenistic oval shield representations from the Bospor kingdom (after Pruglo 1966).

Fig. 11. On the right: statuette of a Celtic mercenary from Egypt after Cunliffe (2000); on the left: statuettes of the 'warriors' from the Kingdom of Bospor after Pruglo (1966).

Fig. 12. Barbarian coins from the Dniester estuary (Odesa Numismatics Museum).

Fig. 13. The bronze La Tène neck-rings from the territory of Ukraine (after Bobrinskij 1910; Khanenko, Khanenko 1900; Pryhodniuk 1980).

Fig. 14. The early La Tène fibulae from the lands of Ukraine eastward of the Carpathians (after Ambroz 1966; Bidzilya, Shhukin 1993, Petrov 1961).

Fig. 15. The rare types of middle La Tène fibulae from the territory of Ukraine (after Ambroz 1966; Babeş 2005, Pachkova 2006).

Fig. 16. The early La Tène arm-rings from the lands of Ukraine to the east of the Carpathians (1,2 - National Museum of History of Ukraine, Kyiv; 3 after Ganina 1965; 4 after Woźniak 1974).

Fig. 17. La Tène wheel-made pottery from Bovshiv (after Krushelnickaya 1965). 